\title{
Female Glass Engravers in the Early Modern Dutch Republic
}

\author{
MARTINE VAN ELK, California State University, Long Beach
}

\begin{abstract}
This essay explores glass engravings by Dutch authors Anna Roemers Visscher, Maria Tesselschade Roemers Visscher, and Anna Maria van Schurman. I place these engravings in their rich contemporary contexts, comparing them to other art forms that were the product of female pastime. Like embroidery, emblems, and alba amicorum, engraved glasses combined text and image, transforming each glass into an object that fulfilled key social and cultural functions. Above all, engraving glasses allowed women to forge new self-representations, specifically through their use of play to question binary oppositions and moral certainties.
\end{abstract}

\section{INTRODUCTION}

IN 1619, THE poet, diplomat, and courtier Constantijn Huygens (15961687) wrote a poem entitled "On the Diamond Pen of Miss Anna Roemers," recording his impression of a glass engraving by the well-known poet Anna Roemers Visscher (1584-1651). He called her pen "a frozen drop of the liquid of Hippocrene," the mythical spring of the muses that gives rise to poetic inspiration. ${ }^{1}$ While he saw glass engraving itself as "such strange work," he thought of the act of engraving as "the quick draw on the glass page / Of the Visscher girl's hand."2 For Huygens, in other words, glass engraving was similar

Venturing into interdisciplinary analysis is impossible without support. My thanks go to Lia van Gemert for her encouragement and to the RSA for organizing its annual conference, at which I first presented some of my readings of these glasses and by which I continue to be inspired. I would also like to express my gratitude to the two anonymous readers for $R Q$ for wonderfully helpful comments on this essay.

${ }^{1}$ The original is entitled "Op het diamantstift van joff ${ }^{\mathrm{w}}$ Anna Roemers" and speaks of "een bevrosen dropp van Hippocrenes nat." It was first printed in 1625 in Otiorium Libri Sex (Six books of leisure hours): Huygens, 1:140. All translations from Dutch are mine unless otherwise noted.

${ }^{2}$ Huygens sees it as "den snellen treck op het gelasen bladt / Van 't Visscher meysgens handt.” He calls engraving "zoo vremden werck": Huygens, 1:140.

Renaissance Quarterly 73 (2020): 165-211 (C) The Author(s) 2020. Published by the Renaissance Society of America.

doi: $10.1017 /$ rqx.2019.492 
to drawing and writing, and it seems no accident that the three Dutch women who were best known for glass engraving, Visscher, her younger sister Maria Tesselschade (1594-1649), and renowned scholar Anna Maria van Schurman (1607-78), were also poets. Yet glass engraving cannot simply be understood as writing on a different surface than paper. Truly "strange work," glass engraving, this essay will show, should be situated at the intersection of multiple artistic and generic domains, some of them art forms customarily practiced by leisured women, such as drawing, writing, embroidery, and painting, but others more commonly identified as male genres, such as copper engraving and emblem writing. Much like other decorative objects that were the product of elite pastime, engraved glasses were presented to friends and acquaintances, gaining social status for the giver and the recipient of the glass. But the glass engravings I discuss had meaning beyond the context of personal gift exchange, not only because some were intended for presentation at public occasions, but also because they became the subject of poetry, ensuring them a presence in print and giving them a cultural impact beyond their immediate context of creation and use.

This essay explores glass engravings by the Visscher sisters and Van Schurman, along with the textual traces their glasses have left behind. After a brief introduction to the art, an examination of their representation in poetry and letters, and a discussion of their artistic and cultural context, I read the glasses closely to show how their intriguing combination of object, image, and text opened up complex meanings. In being engraved and subsequently displayed and written about, I argue, these glasses gained social, cultural, and political significance: socially, engraved glasses cemented relationships, enhanced status, and were used for purposes of self-positioning; culturally, they allowed for reflection on the relationship between art and nature; politically, they participated in discourses of national identity and gender. This meant that women engravers could contribute to debates from which they were ordinarily excluded and take charge of their representation. At the same time, while it is possible to trace their various uses and meanings in the three realms I identify, there is a playfulness about the glass engravings, suggestive of Dutch culture's investment in play as a means of social interaction and artistic expression. This playfulness relies on and is enhanced by the multifaceted nature of engraved glasses as objects. In a culture to which, in Svetlana Alpers's words, "the eye was a central means of self-representation and visual experience a central mode of selfconsciousness," engraved glasses added text, touch (in handling the glass, touching the engraving), and taste (in drinking from it) to sight. ${ }^{3}$ Given that text,

${ }^{3}$ Alpers, xxv. 
image, and materiality can each enhance or subvert each other, glass engraving provided an opportunity for unusual modes of self-expression. The playfulness that results upends convention and undermines definitive readings of the glasses, suggesting the extent to which the engravings' meanings vary depending on the context in which the glasses were engraved, presented, touched, used, displayed, and textually represented.

The technique used to engrave glasses, called line engraving or diamond point engraving, was distinct from the wheel engraving technique that would become fashionable late in the seventeenth century. In the Dutch Republic, the majority of glasses chosen for engraving were roemers; these, like the related glass type called the berkemeyer, were made from Waldglas, or forest glass, green or light brown in color and decorated with prunts. ${ }^{4}$ Frequently imported from Germany, roemers and berkemeyers had a long history and were used across the social spectrum, as their presence in numerous paintings and engravings suggests (fig. 1). From the mid-sixteenth century onward, expensive imported Venetian goblets and their imitations, glasses à la façon de Venise (in the Venetian manner), gained ground. While these luxury items were initially only available to the rich, over time they became cheaper, displacing the berkemeyer. The roemer, however, remained popular well into the eighteenth century. ${ }^{5}$ Roemers varied in size; Harold Henkes's catalogue of glass includes miniature versions as small as 1.4 inches in height and one as tall as 11.5 inches, big enough to hold multiple bottles of wine. ${ }^{6}$ Henkes documents that gradually smaller-sized and more elegant roemers became fashionable; large-sized ones for "communal usage" on festive occasions became much less common. ${ }^{7}$ A variety of roemers and some berkemeyers were selected for engravings; Venetian-style goblets were less frequently engraved due to their thin glass, which made them more likely to break.

The available evidence indicates that glass engraving was not a professional activity in the Dutch Republic_-glasschrijver (writer on glass) is a category in guild records for the Saint Luke's Guild in Delft, for instance, but this word

\footnotetext{
${ }^{4}$ Although she concentrates on a time when Bohemian and English glass had come to dominate the market, Laan has found many eighteenth-century roemers in pits outside inns in the provincial Low Countries. A useful overview of the history of glass in the Low Countries is given by Henkes.

${ }^{5}$ Henkes describes the competition between glass types and the gradual displacement of glasses made of Waldglas by glasses à la façon de Venice. By 1700, he writes, Bohemian glass and English crystal had become the most popular: Henkes, 123.

${ }^{6}$ Henkes, 194, 257.

${ }^{7}$ Henkes, 256.
} 


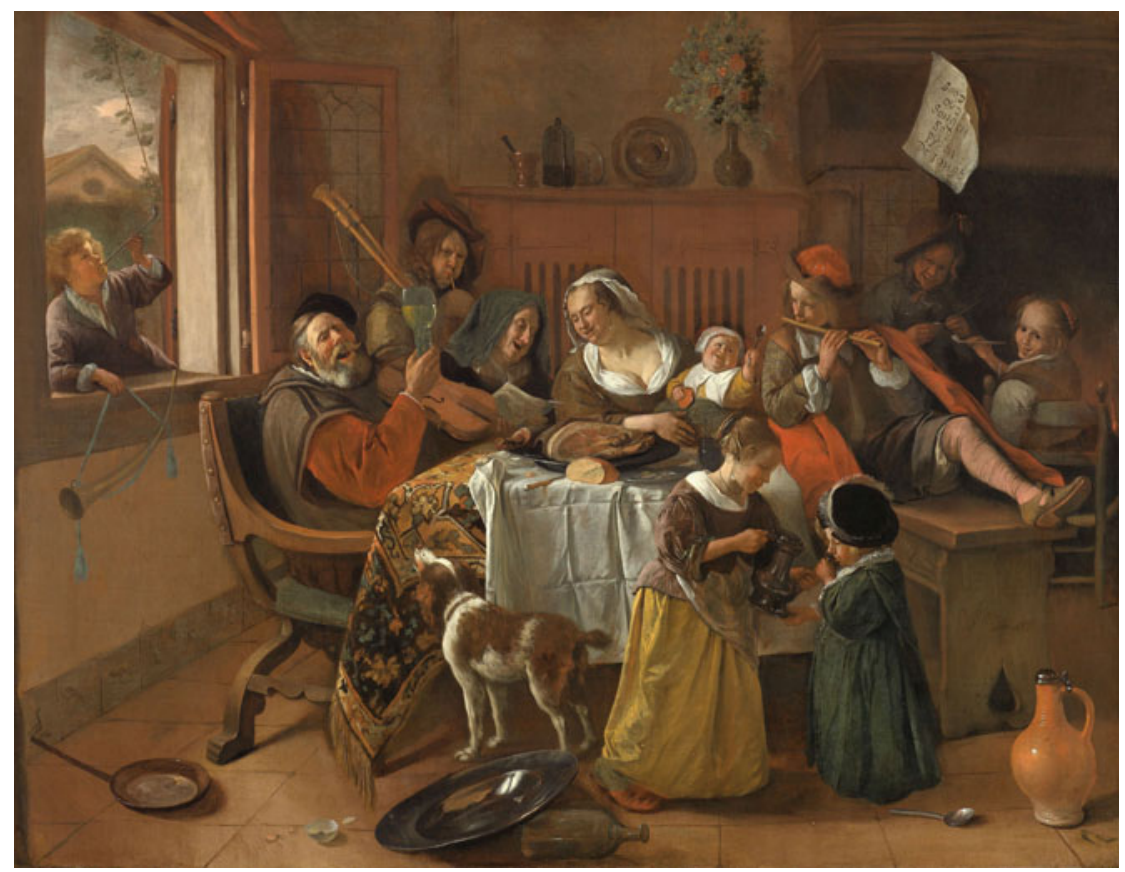

Figure 1. Jan Havickszoon Steen. Het vrolijke huisgezin (The merry family), 1668. Oil on canvas. Rijksmuseum, Amsterdam, SK-C-229.

referred to those who enameled glass, a profession that was dominated by men. ${ }^{8}$ Glass engraving, by contrast, seems to have been a pastime for elite women and men, though it is difficult to assess how commonly it was practiced. Indications are that it was a distinctly Dutch art form. In his catalogue of pre- 1900 European line engravings on all types of glassware, Frank Smit writes that 80 percent of 113 known engravers were Dutch; 79 percent of 2,557 documented diamond point glass engravings on a variety of objects hail from the Low Countries. ${ }^{9}$ In the late seventeenth century, the art was dominated by men like François Crama (1637-1718), Mathieu Petit (ca. 1655-1721), Bastiaan Boers (1650-1713), and Willem Jacobszoon van Heemskerk (1613-92). They were of the middling professional class: while Van Heemskerk was a clothworker and merchant, the others were schoolteachers and calligraphers. ${ }^{10}$ This male dominance belies the centrality of women to the art form: Smit's

${ }^{8}$ For the period 1613-1714, Kloek finds four women among 146 individual names registered as glass sellers and glass "writers," but all four were listed as sellers only: Kloek, 12.

${ }^{9}$ Smit, 1989, 10, 5.

${ }^{10}$ Moerman; Ritsema van Eck. 
extensive research has confirmed that Anna and Tesselschade were among the first to practice glass engraving in the Low Countries.

Complicating factors in assessing who engraved what and how many Dutch men and women engaged in engraving are the ephemeral nature of the glass and that many engravings were anonymous. There are extant signed glasses by Anna Roemers Visscher and Van Schurman, while others have been attributed to them and Tesselschade with a good degree of certainty, but no glasses signed by other women survive. Five of Anna's glasses are extant out of twenty-six referred to in poems and other documents (though there may be some overlap in the references). A sixth glass was last seen at an exhibition in 1913 and subsequently disappeared; a seventh was accidentally broken in a museum in 1939. ${ }^{11}$ For Tesselschade, two out of thirteen glasses remain that have been documented in poems and letters. ${ }^{12}$ Three out of eight recorded glasses by Van Schurman have been preserved. In all likelihood, all three women engraved more glasses than scholars have been able to trace.

Aside from the three examined here, a small number of other women who practiced diamond engraving on glass can be identified. Margareta van Godewijck (1627-77) wrote a poem on her glass engravings. ${ }^{13}$ In De groote schouburgh der Nederlantsche konstschilders en schilderessen (Great theater of Dutch painters and paintresses, 1718-21), Arnold Houbraken (1660-1719) praises Van Godewijck and the versatile artist Joanna Koerten (1650-1715) for glass engraving. ${ }^{14}$ Huygens, whose correspondence and poetry have been helpful in locating a number of female engravers, received a glass with a poem from the Frisian woman Eelckje van Bouricius (1620-82), though the glass has not been preserved and it is not certain that it was engraved. Still, considering other praise for Van Bouricius's engraved glass, it seems likely. ${ }^{15}$ Huygens composed a poem about an engraved glass by Charlotte van Santen (d. 1644) and two poems about an engraved roemer by Cornelia Kalf (16341711), the wife of painter Willem Kalf (1619-93). ${ }^{16}$ The painter Margareta Maria de Roodere (ca. 1625-66) was praised for glass engraving in a poem

\footnotetext{
${ }^{11}$ Smit, 1990, 52-53.

${ }^{12}$ The numbers are based on the listings in Smit, 1990. There may be some double counting.

${ }^{13}$ Van Godewijck, 223.

${ }^{14}$ Houbraken, 1:317, 3:293. Houbraken, 2:209, praises Catharina Oostfries (ca. 16361708) for glass painting, which refers, like glass writing, to enameling and cannot be counted as engraving.

${ }^{15}$ For more on Van Bouricius as poet and her view of various forms of applied arts and poetry writing as analogous, see De Jeu.

${ }^{16}$ For Van Santen, see Huygens, 4:21; for Kalf, see Huygens, 6:263; Van Gelder.
} 
written on the occasion of her wedding. ${ }^{17}$ Elizabeth Crama (1672-1721), a female calligrapher and daughter of François Crama, may have engraved glass, though the signatures on glasses she potentially engraved are ambiguous and could refer to her father. ${ }^{18}$

Among glass engravers, Anna Visscher was a dominant figure, pioneering techniques such as stipple engraving and setting the course for the Dutch style of featuring calligraphic lettering and small depictions of plants and insects on glass. ${ }^{19}$ Van Schurman, a stunningly versatile artist in different media, was inspired by the engravings of the Visscher sisters, but also pushed the boundaries of the art further. Surveying Van Schurman's glass engravings, Katlijne van der Stighelen has discussed some of the glasses that have been lost; she speculates, given a remark by Van Schurman in a 1643 letter, that she may have used wheel engraving-like Visscher's stippling, a brand-new technique that was not practiced widely in the Low Countries until much later. ${ }^{20}$ Beyond the work of Van der Stighelen and the catalogues by Smit, very little research has been done on these glasses in recent years, particularly with regard to their significance as female-authored works of art and the question of their social, cultural, or political importance. ${ }^{21}$

Glass engraving was often grouped with other activities that were seen as proper pastimes for women, such as embroidery, painting, drawing, paper cutting, and writing poetry. Not surprisingly, early modern women themselves perceived their pastimes as connected artistically and substantively; this was especially true for glass engraving, which incorporated other pastimes like engraving and drawing images of insects and flowers. ${ }^{22}$ The first mention of engraving by the Visscher sisters was in this context. The diplomat Ernest Brinck (1582-1649) visited their household in 1612 and noted that they were able to "make music very beautifully, paint, cut in glass, or engrave, make poem[s], invent emblems, all kinds of samplers of embroidery, also good swimming, and have taught themselves in their father's garden, where

${ }^{17}$ Bok and De Meyere, 299.

${ }^{18}$ In a 1970 essay, Strauss claimed to have identified five glasses as engraved by Crama, but none of them have signatures that match her initials; the Rijksmuseum identifies its glass as by her father, François Crama. Smit also asserts that these glasses are engraved by her father, noting that Elizabeth was too young to be the engraver: Smit, 1989, 37. See Moerman, 24-25.

${ }^{19}$ Van der Stighelen, 195. See also Smit, 1993, 5.

${ }^{20}$ Van der Stighelen, 197.

${ }^{21}$ Smit, 1989, 1990, and 1993; Van der Stighelen, 194-211.

${ }^{22}$ In her work on embroidery, Frye has pointed out that "for many early modern English women, writing, visual design, and needlework were not considered mutually exclusive activities; rather, they were related ways to create texts": Frye, 3. While I am arguing that engraved glasses were much more than text, the connection between art forms is important. 
there was a canal with water extra urbem [outside the city]." 23 Brinck was primarily concerned with these activities as evidence of an impressive, comprehensive humanist education. Although he does not mention it, in the first half of the seventeenth century calligraphy would come to fulfill the same function, even though it had customarily been practiced in male-dominated educational settings to prepare for professional activities. In fact, the popularity of calligraphy soared in the early seventeenth century, as the publication of copybooks (calligraphic handbooks) testifies. Glass engravers of necessity had to be good calligraphers; Anna and Tesselschade used calligraphy in their manuscripts and letters, and Van Schurman was particularly well known for her skill in the art. $^{24}$

Brinck's list of accomplishments is unusual in its inclusion of the composition of emblems, an art form that was very popular in the Dutch Republic. Roemer Visscher (1547-1620), the father of the Visscher sisters, published a book of emblems entitled Sinnepoppen (Meaningful images, 1614) in which he says that for him emblems originated in social exchange. He says that he showed his images and inscriptions to friends, asking them to come up with emblematic explanations. ${ }^{25}$ Very few women engaged in published emblem production, however, with the notable exception of Anna Visscher herself, who translated the emblems of the Protestant French author Georgette de Montenay (1540-81) and edited and added to her father's emblem book. The inclusion of "emblem inventing" in Brinck's list suggests a social as well as a performative component to this activity in this particular household: the Visscher sisters may have composed emblems in front of guests, much like they might play a musical instrument, and at the very least they must have showed their emblems to others. Some accounts of glass engraving, as shall become clear below, also imply a performance; Anna engraved on at least one occasion in front of others at dinner, and poems, such as Huygens's cited at the opening of the essay, suggest that poets witnessed her in the act of engraving glass.

${ }^{23}$ They could "zeer fraai muziek [maken], schilderen, in glas snijden, ofte graveren, referein maken, emblemata te inventeren [uitdenken], allerlei manufacturen van borduren, ook goed zwemmen, en het zich geleerd hebben in haar vaders tuin, alwaar een gracht met water was extra urbem": A. R. Visscher, 1999, 13. Other products of the sisters' pastime activities, with the exception of their writing and, for Anna, the composition of emblems, have not survived.

${ }^{24}$ Van der Stighelen, 212-39.

${ }^{25}$ R. Visscher, $1614 \mathrm{~b}$, fol. $* 2^{\mathrm{r}}$. The translation of the word Sinnepoppen is tricky since Visscher himself invented the word. Sin means "meaning" and pop "image" or "picture"hence I have chosen to translate the word as "meaningful images." 


\section{THE GIFT ECONOMY}

Many elite pastimes were not merely educational but also produced objects that could be exchanged with friends and offered to patrons. Most engraved glasses were presented to others as meaningful gifts. ${ }^{26}$ As Victoria Yeoman puts it when discussing decorative trenchers, such objects "played powerful mediatory roles in social relationships and were, therefore, 'agents' of human sociability." 27 In this sense, engraved glasses participated in the same gift economy as poetry, embroidery, paintings, drawings, paper cuttings, and even calligraphy. Calligraphic texts were sometimes given to others for display in the home. Much Dutch poetry also had a social component; it was often directed to friends and composed to offer to others on important occasions such as weddings and birthdays. Embroidery was presented to friends and patrons, potentially carrying political messages and gaining a public edge, particularly when the recipient was of high social status and cultural importance. ${ }^{28}$

Additionally, glass engravings also performed functions similar to alba amicorum. These friendship albums featured contributions collected over the years from close friends as well as acquaintances. Inscriptions could consist of mottoes, short poems, moralistic phrases, and signatures, many in calligraphic form and often accompanied by a miniature image. While alba were usually owned by men, there were some that belonged to women, and women like the Visscher sisters and Van Schurman inscribed them, often with poems in artful handwriting. ${ }^{29}$ Emblem books could also be used as alba, deliberately including empty space to allow for inscriptions by friends. One of Anna Visscher's copies of De Montenay's Emblèmes ou devises chrestiennes (Christian emblems or devices, 1567/71) features translations of the poems by Visscher and another author, suggesting that it was circulated much like an album amicorum. ${ }^{30}$

When products of leisured pastime were circulated, they gained significance beyond the individual household as they were displayed to and used by family and friends of friends, serving to boost the recipient's and the artist's position in social and cultural networks. As Elizabeth Honig has argued, women did not simply function as "amateurs" in what she calls "a broad arena of elite social production and appreciation." 31 The lines between amateur and professional are not clearly drawn: some women artists got larger cultural recognition and

${ }^{26}$ For gift exchange in the Low Countries more generally, see Thoen.

${ }^{27}$ Yeoman, 757. She relies on Gell, who saw objects as "social agents": Gell, 17.

${ }^{28}$ See Klein; Frye.

${ }^{29}$ Van der Stighelen, 212-39. See Reinders for an in-depth exploration of alba owned and inscribed by a provincial network of elite Dutch women.

${ }^{30}$ Margolin, 422; Van Elk, 2009.

${ }^{31}$ Honig, 31-33, esp. 32. 
payment for their work, and the lack of professional status does not necessarily mean they were less accomplished as artists. On the contrary, Honig argues, it was women's position outside of guilds that enabled some of them to break artistic ground. ${ }^{32}$ This could in turn lead to professional recognition: Van Schurman's portraits, for instance, made her an honorary member of the Saint Luke's guild in Utrecht in $1643 .^{33}$

The engraved glasses of the Visscher sisters and Van Schurman, while not produced in exchange for payment, were not always created on their own initiative. All three women engraved glasses on request, including following specifications for the design, and they were commissioned to produce glasses by both individuals and institutions for special occasions. Pieter Corneliszoon Hooft (1581-1647), the Dutch Republic's most prominent poet and historian, was a key recipient of engraved glasses, particularly from Tesselschade. Her glasses affirmed her close relationship to Hooft, her friend, mentor, and patron; he commissioned and designed many of them. Eleven of the thirteen glasses engraved by Tesselschade that are extant or mentioned in documents were for or related in some way to Hooft. A letter by the poet dated 2 November 1632 discusses eight glasses as he talks about three engraved roemers he has received from Tesselschade—one for his wife, one for his stepdaughter, and a large roemer with the inscription "A demain les affaires" ("Leave serious matters to tomorrow"), which he says has been broken. Hooft tells her he is sending her five roemers, a large one and four smaller ones, and asks her to engrave them for him, promising appropriate return and use at a banquet to celebrate her wedding anniversary. ${ }^{34}$ Specifically, he asks for a replacement of the broken roemer with the same inscription, and he requests that two small roemers on silver stands, which suggests they were for display, be engraved with the phrases "Speculum mentis" ("Mirror of the mind") and "Fomentum amores" ("Love potion"). For the benefit of those who do not know Latin, he asks her to inscribe the remaining two roemers, also to be put on silver stands, with the equivalent phrases "Mirror of the inner self" and "Thawing liquid on the love frost." ${ }^{35}$ This unusually large commission caused problems for Tesselschade, who only completed the two glasses with the Latin engravings. An archaeological dig of a pit outside Tesselschade's house has turned up broken glass with lettering on it, including two fragments reading "Dem. .." and "...

${ }^{32}$ Honig, 33.

${ }^{33}$ Honig, 33.

${ }^{34}$ M. T. R. Visscher et al., 97-99.

35 The phrases read "Spieghel van de binneborst" and "Doojnat op de minnevorst." M. T. R. Visscher et al., 97. 


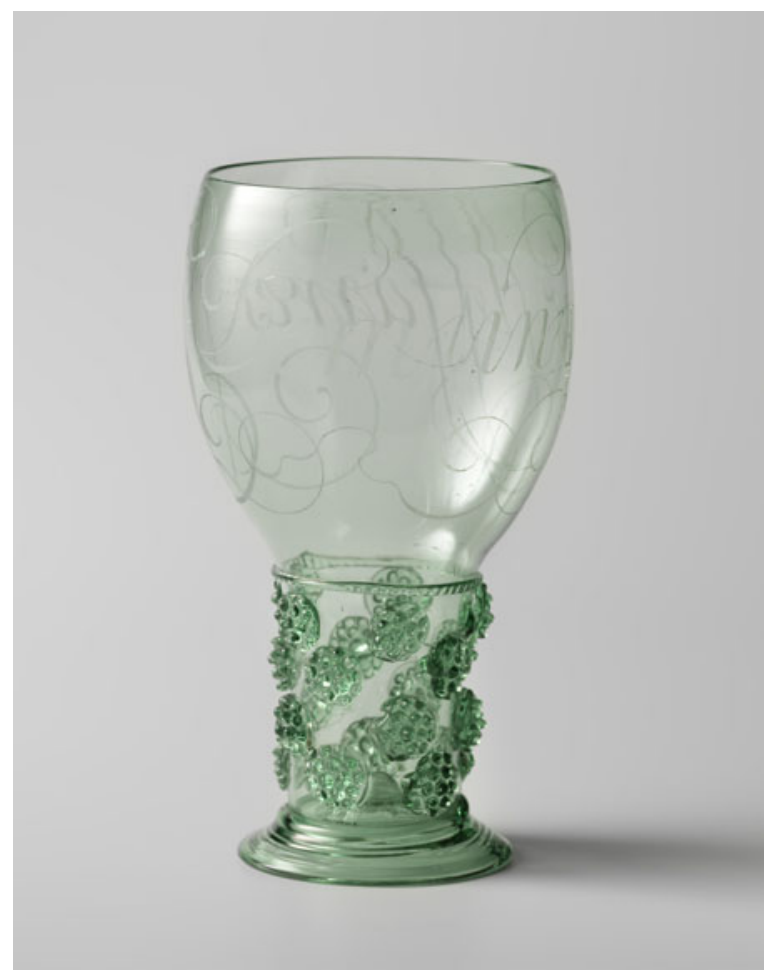

Figure 2. Maria Tesselschade Roemers Visscher. “A demain les affaires,” ca. 1625-ca. 1649. Engraved roemer. Rijksmuseum, Amsterdam, BK-NM-8187.

aires." 36 This information makes it, as is generally accepted, highly likely that an extant engraved roemer in the Rijksmuseum with "A demain les affaires" on it is a later engraving by Tesselschade to replace the broken original (fig. 2).

Another commission came on 13 January 1643, when Hooft asked Tesselschade to engrave two roemers with his and his wife's mottoes along with images of their personal blazons: a sun (for him) and a field with three bushes with white lilies (for his wife), "the way I have scribbled it under here." ${ }^{37}$ At this point, he was apparently aware of the fact that Tesselschade had a skin infection on her hands, making the work potentially difficult. For this reason, he adds that if it is too hard for her to engrave the glasses, surely her sister will do it. ${ }^{38}$ The letter sounds more like a business transaction than a

${ }^{36}$ See "Gegraveerd."

${ }^{37}$ There is a picture underneath. He asks her to do the engraving, "gelijk jk het hier onder gekrabbelt heb": M. T. R. Visscher et al., 270.

${ }^{38}$ M. T. R. Visscher et al., 270. 
request from a friend, and Mieke Smits-Veldt reads it as a sign that their friendship had cooled after Tesselschade's conversion from the Protestant to the Catholic faith in $1641 .{ }^{39}$ Gifts of engraved glasses could, this suggests, be situated on a spectrum between amateur and professional, taking the forms of friendly gesture or gift, donation with expected return, or detailed commission.

\section{TEXTUAL REPRESENTATIONS}

Because of their place in the gift economy, many engraved glasses survive only in textual form: once offered to someone, the return would be a poem expressing thanks, and these poems frequently found their way into printed volumes. Most glasses by the Visscher sisters were presented to poet-friends who were also important figures of cultural authority in the Dutch Republic, and this led to their wider textual circulation. Given its social context, engraving often features as part of a catalogue of artistic skills of the engraver. This representation, perhaps not surprisingly, cannot accommodate the physicality of the act of cutting into a surface. Poets often avoided using the normal term for engraving, snijden (cutting), in favor of the courtly elegance and graceful action of the female hand. The poetic emphasis on sprezzatura contrasts with the reality, witnessed, for example, in Tesselschade's apologetic description of her attempts at engraving the glasses Hooft commissioned from her in his 1632 letter: "I have been preoccupied bravely with cutting; the first has been broken, and also the Dutch are too many letters; it is not working out; it looked too scratchy; have therefore chosen the Latin." 40 Such struggles with the material features of the glass surface are sidestepped in many poems. Instead, the poems express ambivalence about the type of agency that is accorded to the female engraver, but however they present this agency, they all highlight the transformative effect of engraving, on the glass, on the beholder of the glass, and even on the engraver herself, using the kind of playfulness that is key to the glasses themselves.

The classical scholar Daniel Heinsius (1580-1655) was an early patron and admirer of Anna Visscher and acquainted a larger public with her poetry and art in his Nederduytsche poemata (Dutch poems, 1616). Praising her accomplishments, Heinsius makes the conventional connection between engraving and other pastimes. Each tool used by Anna, from paintbrush to needle, gives way to her desires, he claims, but engraving stands apart from the others:

\footnotetext{
${ }^{39}$ Smits-Veldt, 91.

${ }^{40}$ The letter reads, "ick heb dapper besich geweest met snijen; de eerste is gebroecken, en ock het duyts zijn te veel letteren; wil soo wel niet vallen; het stont te krivelich; heb[b]e daerom het latijn gekooren": M. T. R. Visscher et al., 99-100.
} 
... but most the Diamond,

Because he is worthy, in your worthy hand.

He draws everything you want, and seems to wait on you,

As slave to your spirit and soaring thoughts. ${ }^{41}$

He describes engraving as if he has witnessed it, rather than concentrating on the finished product, treating it as akin to drawing. Resisting a bodily representation of Anna, Heinsius creates a scenario in which the anthropomorphized diamond, rendered "worthy" by being placed in her hand, becomes a courtly lover, servant, and slave to the engraver. Engraving is a male act, performed at the behest of Visscher, but not by her directly. At the same time, her "spirit and soaring thoughts" attribute to her mind a good deal of power, even if that power is rendered physically safe.

Huygens used metaphors that were even more creative when describing engraving, specifically connecting Visscher's artistic accomplishment to Dutch national identity. In one poem, for instance, he treats engraving as ice skating, which he calls laveren (tacking), a sailing term for the way a ship moves back and forth when going into the wind:

Over [glass] you tack back and forth

With far more wondrous strides,

With far more wondrous strokes

Than the Amstel has ever carried

When he was covered and encrusted by the Winter Frost. ${ }^{42}$

Even as he euphemistically foregrounds the graceful movement of the diamond pen, his image is also striking because it features Anna skating. At the same time, it helps him situate her artwork geographically. This use of winter imagery gains meaning beyond the individual engraver if it is read in light of his 1619 poem cited at the opening. A contemplation of Anna's pen, the "frozen drop of the liquid of Hippocrene," leads to a challenge to people from warmer countries:

Go, Stranger, despise our cold northern lands,

By the hot, fertile sand of your scorched beaches,

Accuse our frost of little fruit or none:

Has China, has Peru, have the Indies heard

${ }^{41}$ He writes, "maer meest de Diamant / Om dat hy weerdich is, is in u weerde handt. / Die treckt al wat ghy wilt, en schijnt op u te wachten, / Als slaef van uwen geest en vliegende gedachten": Heinsius, fol. $\mathrm{E}^{\mathrm{r}}$.

42 "Daer laveert ghy over heen / Met veel wonderlycker schreên, / Met veel wonderlycker slagen / Dan oyt Amstel heeft gedragen, / Als hy vanden Winter Vorst / Was besloten en vercorst": Huygens, 1:140-41. 
That out of his warm lap has ever come forth

More costly wet, more artful stone? ${ }^{43}$

While this final image concentrates on the diamond in the engraver's pen, the bodily representations of Anna as ice skater and the glass as "more costly wet," compared to the fruit coming from the "warm lap" of other countries, are surprisingly physical. Thus, the act of engraving enables a playful construction of national identity that can accommodate both erotic connotations and a representation of a physically graceful yet active woman engraver.

Equally interested in the sexual connotations of engraving, Hooft locates erotic desire in the engraver, the image, and the beholder of the glass in a 1621 sonnet dedicated to Anna:

When you desire, with diamond, to stipple on a glass

it is as if you are breeding butterflies. The ingeniously depicted creature

looks as if it is seeking to quench its thirst with juice of grapes

and sits so elegantly, one would clip it off the roemer. ${ }^{44}$

Hooft presents Anna as more actively producing the engraving than Heinsius, comparing it to "breeding" the butterfly. This act of breeding, initiated by the engraver's desire, leads to a curious, erotic rivalry between drinker and butterfly as both long for the wine that is contained in the glass. Ambiguities in the wording give rise to additional meanings that are difficult to capture in translation. First, in describing the way the butterfly is sitting, Hooft chooses the word kuin, which can be translated either as loosely (in the sense of unsteadily) or elegantly. ${ }^{45}$ In the latter case, it is the impressive quality of the image that makes the beholder desire to take the butterfly off; if one chooses the former reading, the beholder of the engraving is responding to the fact that the butterfly is already sitting unsteadily, which makes the act of removing the butterfly seem less violent. Second, the word knippen also had multiple meanings. The

43 "Gaet, Vreemdelingh, veracht ons coude noorder landen, / By 't heete vruchtbaer sand van v versenghde stranden, / Beschuldicht onse vorst van weynich vrucht off gheen: / Heeft China, heeft Peru, heeft Indien vernomen / Uyt synen warmen schoot te wesen voortgecomen / Oyt costelycker nat, oyt constelycker steen?": Huygens, 1:140.

44 "Zo 't u met diamant lust op een glas te stippen / 't is in de vlinderteelt. Het geestige gedrocht / ziet of het lafenis aan sap van druiven zocht / en zit zo kuin, men zou het van de roemer knippen": Hooft, 65. The use of stippen (stipple) is noteworthy: the first example of the stipple technique is on a glass by Visscher that dates from 1646, twenty-five years after this poem was written. See Van der Stighelen, 195. For stipple engraving generally, see Smit, 1993. Smit identifies this as the first reference to stipple engraving though he sees this as "fine-scratching" technically, achieved "very rarely, and entirely incidentally": Smit, 1993, 5.

${ }^{45}$ See Woordenboek der Nederlandse Taal (hereafter WNT) in De Geïtegreerde Taalbank (hereafter GTB), s.v. "Kuin." 
word was used for trapping prey and for clipping or cutting with scissors. ${ }^{46}$ In the first of these scenarios, the desire of the beholder is imagined as predatory, hunting for the butterfly. The second option makes the beholder take on the cutting action involved in engraving. In either case, Anna is responsible for "breeding" the butterflies, which are so real that they tempt the beholder of the glass to violate her creation.

The link between sexuality and glass engraving and the slippage from admiration into male desire for appropriation can also be seen in Huygens's poems about other female engravers. Like Hooft, he playfully connects the glass to the female body, presenting both as beautiful, graceful, and fragile. An engraved glass by Van Santen, described in a poem written after her death, apparently showed the image of a woman. Reflecting on the glass as equivalent to the engraver, now gone, Huygens writes, that "She wanted to show on a glass / How robust, how beautiful, how brittle she was." 47 The word kloek, here translated as robust, can mean stout or sturdy, but also competent, wise, or courageous, allowing him to represent Van Santen and the glass as paradoxically fragile and strong at the same time. ${ }^{48}$

Such a view of the engraved glass as a representation of the engraver can take a more negative turn, particularly if the art is situated outside the realm of pastime. Huygens takes an unusual approach in one of his poems on an engraved roemer by Kalf, suggesting the possibility of a noncourtly, nonaesthetic perspective. The glass is not extant, and nothing is known about the engraving, but Huygens uses it to joke about her name, comparing her hands to a calfs hoofs or legs, for which Dutch uses the word poten. He opens the poem bluntly: "This is the handiwork of a Calf. May I not say hoof-work? / Who doesn't like the word may try to contradict me." In a spin on the compliment paid by Heinsius, he notes that her "calves' hoofs" turn bad goods into goods of higher value and glass into gold "with a pull and a half," but goes on to warn her:

Making gold and selling it

Is secondhand Art: such Gold for my papers [in my opinion?]

Is crazy Merchandise; and if you don't stop it,

Beware of bankruptcy, it is Gold turned into Glass. ${ }^{49}$

${ }^{46}$ See WNT in GTB, s.v. "Knippen," III and IV.

47 "Sij wilde thoonen op een glas / Hoe kloeck, hoe schoon, hoe broos sij was": Huygens, 4:21.

${ }^{48}$ See WNT in GTB, s.v. "Kloek," I.

49 "Dit's 'thandwerck van een Calf. magh ick niet poot-werck seggen? / Die 't woord niet en gevalt magh 't sien te wederleggen." He speaks of her "Calverpootjens" and "anderhalven treck," and warns her, "Goud maecken en vertieren / Is tweederhande Kunst: sulck Goud 
Huygens warns Kalf that putting her art on the market devalues not just the glass but also the engraver. While most poems praise glass engravings and admire their elegance, the desire of Hooft and the threat of Huygens also imply that there is a danger in the transformative effect engravings have on the glass, the beholder of the glass, and the engraver herself.

Female engravers themselves presented their art as modest yet powerful, potentially conferring divine agency on the engraver. Although she frequently uses the term "written upon" ("beschreven") when presenting roemers poetically, Anna also uses the modest verb "scratch" ("gecrabbelt") in a 1642 poem accompanying a glass she presented to Pieter Roose, a prominent politician in Brussels:

I pray to God, that he, what was mine,

With a diamond, scratched in a glass

With his finger will write in Your Honor's heart,

So that Your favor may remain with me forever. ${ }^{50}$

The engraving action is mere scratching, but she hopes that it will bring about divine writing in the heart, creating an inward change in the recipient. Her ambitious wish, in other words, is that engraving, linked with writing, is a powerful act initiated by a woman and carried out by God upon the body and spirit of a man.

Van Godewijck who, like so many of her contemporaries, was accomplished in various art forms, had a similarly ambivalent perspective on engraving. In her poem "On my engraved Roemers," she writes:

When I have been relieved of care and homely Matters,

I take in my room a Roemer in the hand;

I cut something artfully; this can entertain me,

Like Pallas did with the tip of a Diamond. ${ }^{51}$

voor mijn' papieren, / Is dolle Koopmanschapp; en, soo gij 't niet en staeckt, / Schrickt voor de banqueroet, 'tis Goud tot Glas gemaeckt": Huygens, 6:263.

50 "Ik bidde Godt, dat hy, hetgeene van my was, / Met eenen diamant, gecrabbelt in een glas, / Met synen vinger wil in UE herte schryven, / Opdat U gunst tot my mach eeuwichlijcken blyven": A. R. Visscher, 1881, 2:280. Smit, 1990, 50, thinks this was the phrase engraved on the glass itself.

51 "Wanneer ick ben ontlast van sorgh en huijsche Saken, / Ick neem in mijn vertreck een Romer in de handt; / Ik snijd' iet na de kunst: dit kan mij me vermaken, / Als Pallas dé met 't punct van eenen Diamant." The poem is entitled "Op mijn gesneden Roomers": Van Godewijck, 223. 
Not troubled by the unfeminine connotations of the word snijden, she firmly places glass engraving in the realm of domestic pastime, only permissible when all other duties have been fulfilled. At the same time, she associates engraving with Pallas Athena, a mythological connection that is made repeatedly in textual references to glass engraving. The connection relies on Athena's patronage of crafts, but it also extends to the goddess's skills in weaving, seen in her rivalry with Arachne. Weaving, as Susan Frye points out, is etymologically related to text as well as textile to suggest the textuality of needlework. ${ }^{52}$ The loom, like the needle, can also be equated with the diamond pen, as this reference to Athena appears to do. Further bolstering the importance of engraving, Van Godewijck follows the poem with a Latin quotation she attributes to Pliny, but which comes from Jerome's commentary on the book of Amos, reading, "Whenever fire conquers all, and would consume all metals, [it] renders Diamond purer." 53 This too counters the representation of engraving as insignificant pastime: trial (the fire) makes the virtuous person more virtuous. Although engraving is not explicitly connected to the quotation, the tool of the art is elevated above all other tools. For Van Godewijck, it seems, engraving proves her virtue. These different approaches to female glass engraving, poised between serious self-expression and domestic pastime and between marketable good and purely aesthetic object, are integral to the complexity of the glasses themselves and suggest that giving a glass to someone was as much an act of representing the other as it was an act of representing the self.

\section{SOCIAL POSITIONING AND SELF-REPRESENTATION}

In their most straightforward form, engraved glasses were gifts, designed to emphasize friendship and give thanks. They also enabled hospitality, fulfilling the "mediatory" social function to which Yeoman refers. ${ }^{54}$ As seen in the poems, presenting a glass to a prominent cultural figure such as Hooft or Huygens promised a wider audience, in the form of the recipient's friends and relations and via textual circulation in poems and letters written about it. This means that these glasses can be read for their immediate social valuepositioning within a network, enhancing personal relationships-but also as performances of a more meaningful kind. In engraving glasses for others,

${ }^{52}$ Frye, 14, quotes Woodbridge on the etymology. See Woodbridge, 34.

${ }^{53}$ She slightly misquotes Jerome. Her quotation reads, "Quumque ignis omnia domet, et omnia metalla consumat, reddit Adamantem puriorem": Van Godewijck, 223. The original quotation in Jerome reads, "Cumque ignis omnia domet, et universa metalla consumat, reddit adamentem duriorem": Hieronymus (In Amos, 3.7.22).

${ }^{54}$ Yeoman, 757. 
engravers offered both a self-representation and a representation of the recipient of the glass. Such representations were complicated by the interplay between glass, its function, inscriptions or text on the glass, and the style of the calligraphy. In the case of the Visscher sisters and Van Schurman, these elements combine to formulate unconventional self-representations for the engraver, representations that are particularly important in light of the cultural centrality of these three women as subjects of panegyric and as supposed paragons of female virtue and sophistication. Each approached glass engraving in her own way, creating models of female authorship and artistry that incorporate devotion, temperance, virtue, grace, and especially wit, an intelligent penchant for play that shows a self-conscious desire to challenge conventions of femininity.

The use of glasses as acts of self-representation is explicit in the case of the Visscher sisters. When they chose to engrave roemers they were, by happy coincidence, punning on their patronymic, though Roemer Visscher's first name was in fact derived from the name Romarus. Thanks to this coincidence, glass engravings can be seen as a type of signature for the Visscher sisters that associated them with their father and his ideas as expressed in emblems. He was himself fond of punning on his name, and he included a roemer in the engraving featured on both the title page of his collection of poems, Brabbeling (Babbling, 1614), and of his emblem book, Sinnepoppen. The latter also features a roemer in the emblem's image, or pictura, for his personal motto, "Elck wat wils" (fig. 3), which means "To each his own." 55 Both title page and emblem show a roemer positioned between a wine jug and a water jug; the prose accompanying the emblem explains that the phrase indicates the need to offer each what he or she desires within the limitations of what is available. As Anneke Fleurkens has argued, the image also emphasizes the ideal of temperance, a key component of Roemer Visscher's Stoic worldview. ${ }^{56} \mathrm{He}$ generally rejected courtliness and religious extremes in favor of a tolerant, temperate, and educated sense of Dutch identity. Yet his Stoicism could also be undercut by his interest in wordplay. For instance, Brabbeling includes a number of riddles, one of which is about the roemer. In this early work, the roemer is compared to a woman, with sexual allusions to the prunts on the lower part of the glass, the "smooth mouth" of the glass, and its "clear skirt." ${ }^{77}$ Naturally, the Visscher sisters would have wanted to avoid the more explicit sexual connections between the glass and a woman, but they did use their glasses to align

${ }^{55} \mathrm{R}$. Visscher, $1614 \mathrm{~b}$, fol. $\mathrm{H}^{\mathrm{v}}$ (emblem 2.1). The engraving was later used for the title page of Anna's 1619 edition of her father's emblems.

${ }^{56} \mathrm{R}$. Visscher, 2013, 25-28.

${ }^{57}$ He speaks of the glass's "gladde mont" and "clare rock": R. Visscher, 1614a, fol. N7". Translation by Smit, 1990, 5. 


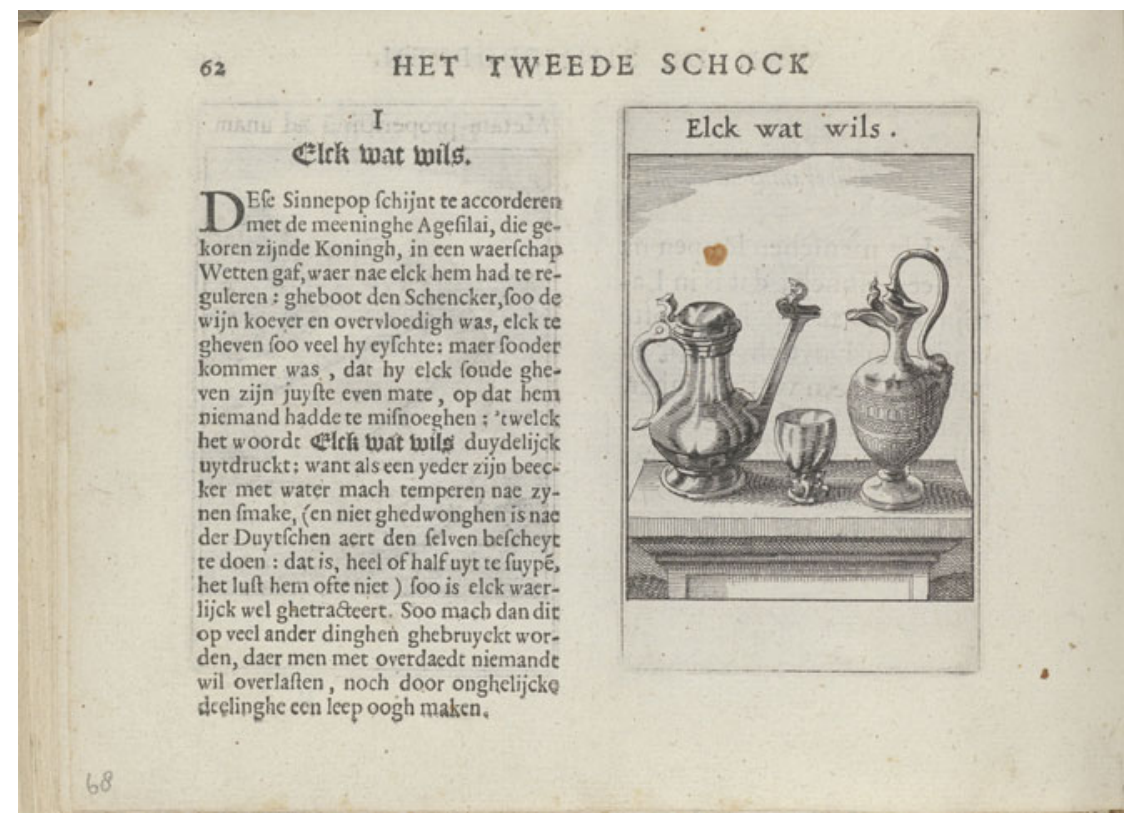

Figure 3. Roemer Visscher. "Elck wat wils," Sinnepoppen, 1614, page 62 (fol. H3", emblem 2.1). Rijksmuseum, Amsterdam, BI-1893-3539-68.

themselves with their father's more serious moral worldview. This association was also confirmed in their choices of personal mottoes. Tesselschade's motto was "Elck zijn waerom" ("To each his wherefore"), a plea for tolerance, and Anna's motto, "Genoegh is meer als veel" ("Enough is more than a lot"), emphasized temperance. Both mottoes had served as titles for emblems in Sinnepoppen, and Anna's motto appeared on more than one of her glasses. ${ }^{58}$

While engraved glasses can be treated as a type of emblematic text associated with the engraver, the engravings themselves are also analogous to emblems in their three-part structure: where the reader of emblems is asked to consider the relation between picture, motto, and poem or prose gloss, the beholder of the engraved glass needs to interpret the relations among image, inscription, and the glass itself. This emblematic quality points to the affinity of glass engraving to art forms and genres that were equally invested in the relation between text and image. Female pastimes, such as embroidery and paper cutting, frequently joined text and image productively, and making this combination for purposes

58 "Genoegh is meer" is the title for emblem 2.7 (fol. I2v); "Elck zijn waerom" for emblem 2.9 (fol. I3 ${ }^{\mathrm{v}}$ ), both in R. Visscher, 1614b. For more on the mottoes, see, for Anna, A. R. Visscher, 1999, 78-79; for Tesselschade, Smits-Veldt, 23. 
of artistic self-expression was a pervasive cultural habit in the period. Objects for domestic use were common vehicles for text and inscriptions, such as those on the "speaking plates" Yeoman has examined. ${ }^{59}$ Moreover, Dutch painting often included text, not simply for moralistic or religious effect but, as Alpers explains in The Art of Describing, to produce an equality between text and image, incorporating the text as image. ${ }^{60}$ In her chapter on textual elements such as letters, inscriptions, and books in Dutch paintings, Alpers argues that these texts do not necessarily sum up emblematically how the picture should be read. Instead, she writes, "they give us more to look at. They extend without deepening the reference of the works." 61 Text and image could combine in a variety of fruitful ways, with text possibly but not necessarily controlling the meaning of the object. As will become clear, even when they featured only text, engraved glasses could playfully undermine the moral sentiment of their inscriptions in their use, their material form, and the shape of their calligraphy.

As a means of self-representation, engraved glasses articulated women's worldviews, while also ascribing those worldviews to the recipient of the glass, who, by subsequently drinking from it or showing it to others, could endorse them. A number of glasses confirm close ties, patronage, and positions in networks, celebrating the use of the glass for drinking wine. Anna's roemer for Hooft with the inscription "Hospitalitatis ergo" (1642) plays with the double meaning of the word "ergo," as both "therefore" and "whence": she offers thanks for hospitality provided by him and allows further hospitality from him. Another glass (fig. 4) features the French inscription, "Vin sans amij joye a demi" ("Wine without a friend, half the pleasure"). Such inscriptions are phrased in the language of friendship and hospitality, the conventional realm within which engraved roemers were situated. Other inscriptions sound authoritative and, in some cases, moralistic, espousing a preference for temperance and virtue. For instance, glasses engraved by Van Schurman often contained moral sentiments that might be expected from the deeply Reformed and devout artist, ranging from "Joy exists, in proper measure" to "Your art, Bacchus, will not please me, but the art of Pallas." 62 The connection between glass engraving and Athena, which, as in the poem by Van Godewijck, is made on the glass itself, draws on references to Athena as patron of crafts and goddess of wisdom; for Van Schurman, Athena is a strong female counter to the foolishness of

${ }^{59}$ See Yeoman, 755; also Fleming, 20, who has analyzed the pervasiveness in the period of texts she calls "portable."

${ }^{60}$ Alpers, 180.

${ }^{61}$ Alpers, 169-221, esp. 187.

${ }^{62}$ The original engravings read "De Vreuchdt bestaet, in rechte maet" and "Non ego bacche tua, sed Palladis arte placebo.” Smit, 1989, 60, 97. 


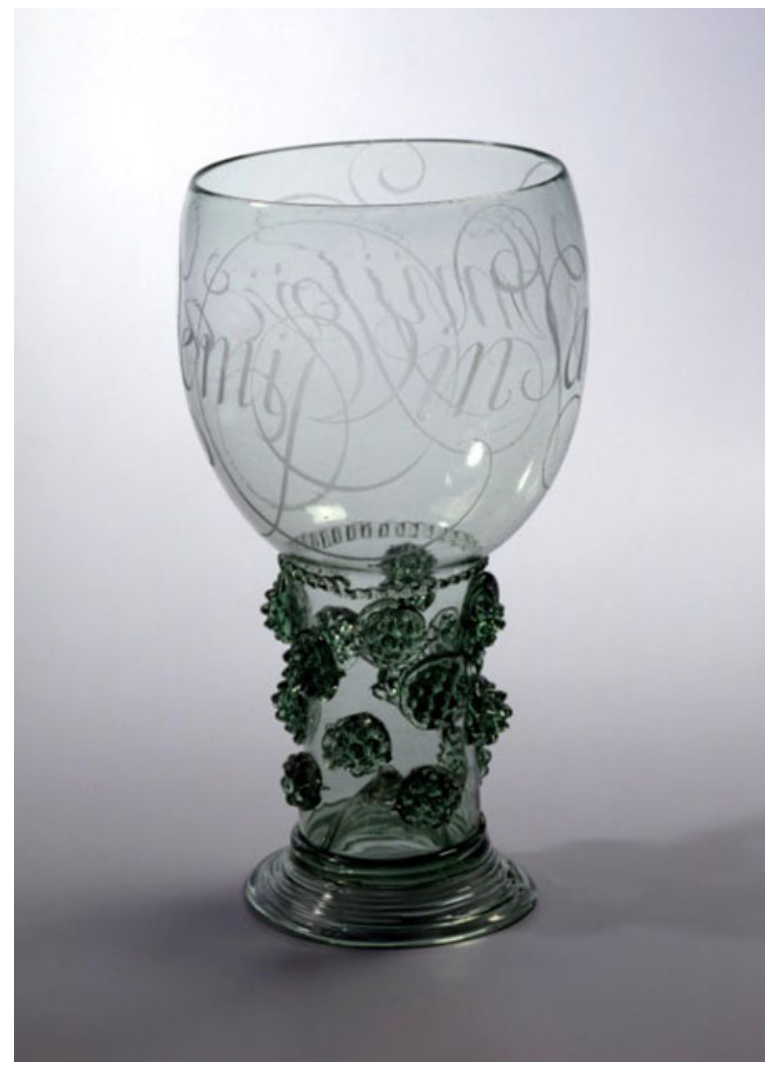

Figure 4. Anna Roemers Visscher. "Vin sans amij," 1646. Engraved roemer. Stichting Slot Zuylen, Oud Zuylen, Inv. nr. 504.

Bacchus, the god of wine, whose importance to the expected function of the glass is obvious. An undated goblet by Van Schurman (fig. 5) has the inscription "Welcome of friends" on the glass itself and "UNFORCED BEST" in roman capitals on the lid, situating it within the realm of pleasurable friendship, but defining it as plain and honest, rather than artificial and conventionally courtly. ${ }^{63}$ Thus, Van Schurman's inscriptions create a deliberate, ironic tension, and they distance the engraver from the supposed purpose of the glass and its potential future misuse.

This moral message in Van Schurman's inscriptions is both confirmed and undercut by the materiality of the objects. Underlining the importance of unforced friendship, the calligraphy on Van Schurman's goblets reinforces

${ }^{63}$ The engravings read "Welkomst der vrinden" and "ONGEDWONGEN BEST." 


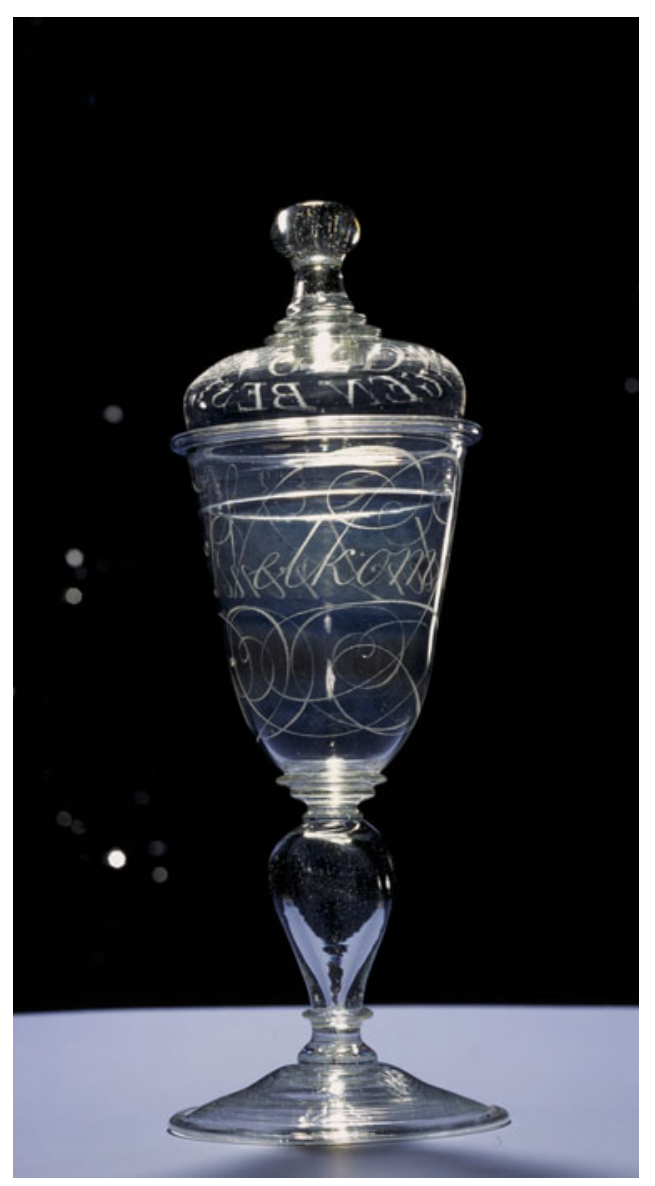

Figure 5. Anna Maria van Schurman. "Welkomst der vrinden," dated by Centraal Museum ca. 1630-ca. 1640. Engraved lidded goblet. Centraal Museum, Utrecht, Inv. nr. 7855.

the impression of both elegance and plainness. She was inspired by the work of the only female professional calligrapher, Maria Strick (b. 1577) (fig. 6), a schoolteacher, whose copybooks were printed and disseminated widely. ${ }^{64}$ Strick's work was probably known to the Visscher sisters and Van Schurman. ${ }^{65}$ Although he does not use religious terms, Ton Croiset van Uchelen describes Strick's calligraphic style as set apart by a "soberness" and

${ }^{64}$ Van Elk, 2018.

${ }^{65}$ Hiddes, $108 \mathrm{n} 4$, cites a mysterious note on a copy of one of Strick's handbooks that claims it belonged to Van Schurman. 


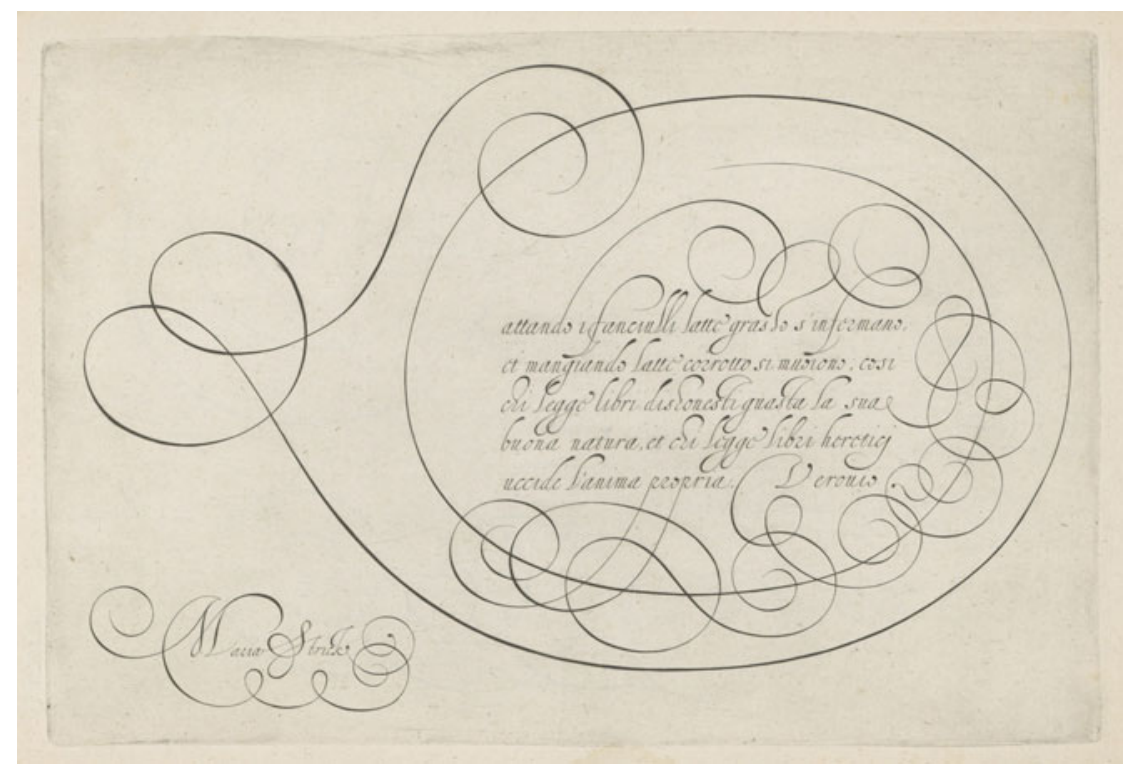

Figure 6. Maria Strick (designer) and Hans Strick (engraver). Schat oft voorbeelt ende verthooninge van verscheyden geschriften (Treasury or example and display of various hands), page featuring the capital letter $L$, Rotterdam, 1618. Rijksmuseum, Amsterdam, BI-1885-1328-14.

"characterized by a 'less is more' philosophy." 66 This style would have appealed to the Stoic impulses of the Visscher sisters and in particular to Van Schurman's devout sensibilities. In their pairing of moral inscriptions with ornate but never excessive calligraphy, her glasses modeled religious conviction and morality. But this emphasis on elegant plainness was also undercut by the glasses she used. Two of the three extant glasses are goblets with lids made of clear glass $\grave{a}$ la façon de Venise. Unlike roemers, which were for daily use, these goblets were employed for decorative purposes in aristocratic households, making them subject to a type of conspicuous consumption against which the inscriptions appear to argue. Moreover, that the nature of their glass made these goblets difficult to engrave rendered their selection for engraving a deliberate display of sprezzatura, an occasion for the kind of excessive praise Van Schurman tended to disavow.

The glass engravings by the Visscher sisters reveal equally complex selfrepresentations. Since Hooft frequently dictated what the inscriptions should read on Tesselschade's glasses, the substantive component of the text is, whenever there is such a commission, his deliberate self-representation as he wants to convey it to his guests. Inscriptions on her glasses are all quotations, derived

${ }^{66}$ Croiset van Uchelen, 118. 
from literary sources. What is notable about some of them is that they create different messages for different readers of the glass, depending on their familiarity with the original context for the quotation. Tesselschade's extant roemer with the inscription "A demain les affaires" is a good example. ${ }^{67}$ In an episode described by Plutarch (ca. 46-ca. 120 CE), the Theban governor Archias pronounces this expression when a messenger interrupts a debauched evening with an urgent letter about a conspiracy against him, a remark for which he pays with his life. ${ }^{68}$ "A demain les affaires" is also the title of an essay by Michel de Montaigne (1533-92), which refers to this episode and contemplates the merits of curiosity versus nonchalance or unconcern, only to conclude that one cannot lay down reasonable rules for human behavior. ${ }^{69}$ Hooft was deeply influenced by Montaigne's work. ${ }^{70}$ Given this context, the engraving gains a double meaning: to the observer with no previous awareness of the phrase, it celebrates the association of the roemer with indulgence, leisure, and hospitality, with a carelessness and lack of morality that is reminiscent of some of the friendship engravings by Anna. But to the reader aware of the allusion to Plutarch and Montaigne, it suggests the potential foolishness of such celebration, creating an ironic gloss on the act of drinking from the roemer. Hooft's double commission of the Latin and Dutch sayings on other glasses shows that he catered to the different levels of education among visitors to his household, and he thought of engraved glasses as having an audience. In other words, glass engravings could be presented by one person to another, but were also household artifacts that conveyed a range of messages to different people. From self-representation by the engraver, the engraved glass became a means of self-representation for the owner.

A similar multivalence can be seen in another inscription on a glass by Tesselschade. This glass is, like her only other extant glass, unsigned, but the style and handwriting make the attribution uncontested (fig. 7), though it is not known if she chose the text herself or not. It bears the Latin inscription "Sic soleo amicos," a phrase from The Eunuch by Terence that means "This

\footnotetext{
${ }^{67}$ Smit claims the source of the phrase "A demain les affaires" is Matthew 6:34, the passage in which Jesus urges his followers to concentrate on the divine in the present day. There may be such an allusion, but the quotation on the glass is not the same as the bible verse he cites. See Smit, 1990, 87. In the translation by Pierre Robert Olivétan, Le nouveau testament (1535), on which John Calvin based his Geneva Bible, the phrase reads, "Ne soyez donc en soucy pour le lendemain" ("Therefore do not worry about tomorrow"): Olivétan, fol. aa.v ${ }^{\mathrm{r}}$.

${ }^{68}$ The story is in Plutarch's Morals, specifically De genio Socratis (On the daimon of Socrates). Plutarch, 2:419.

${ }^{69}$ Montaigne, 2:363-65.

${ }^{70}$ An up-to-date, balanced account of Hooft's use of Montaigne is given by Jansen.
} 


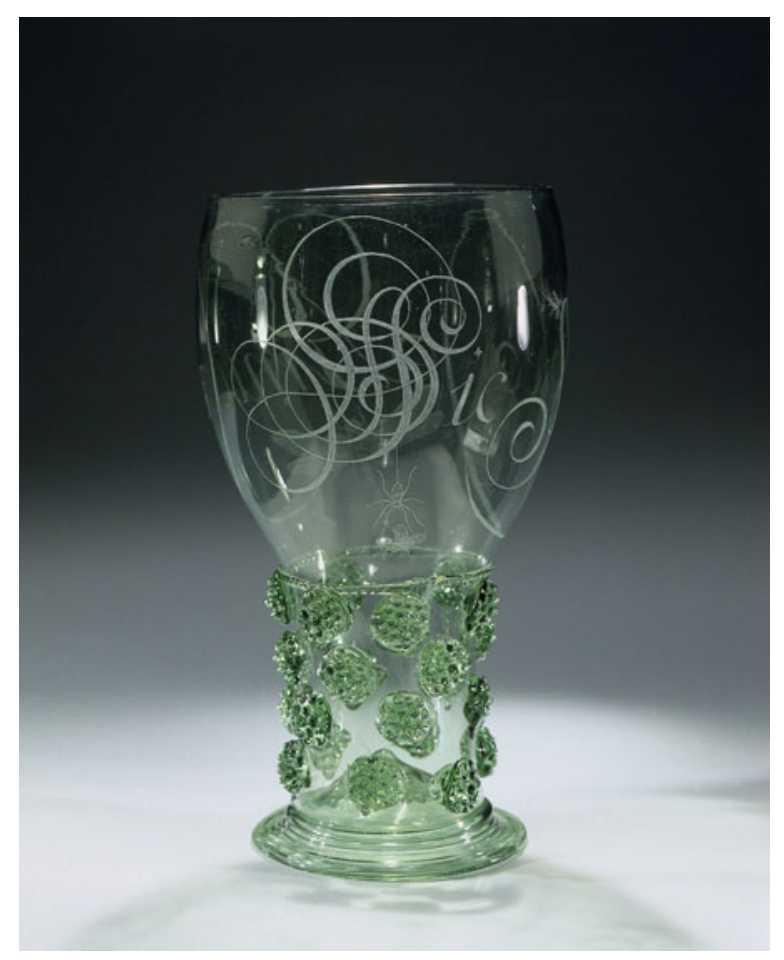

Figure 7. Maria Tesselschade Roemers Visscher. "Sic soleo amicos," ca. 1625-ca. 1650. Engraved roemer. Rijksmuseum, Amsterdam, BK-NM-10754-50.

is how I treat my friends." ${ }^{\prime 1}$ There is mockery in the original quotation, which is said by Gnatho, the play's parasite, to a fellow servant, who sees through his flattery. ${ }^{72}$ As is true for "A demain les affaires," the meaning of the phrase on the glass depends on one's education. In isolation, the phrase points to the function of the glass: in the act of giving the glass to someone, the quotation seems to say, the engraver is proving how she treats her friends; alternatively, in presenting the glass to visitors, the host is proving his or her hospitality. But with an awareness of the original and secondary context, the phrase can serve as a veiled, ironic warning against consuming what is in the glass. Thus, Tesselschade's

${ }^{71}$ Terence, 44 (2.2.279).

72 Jacob Westerbaen (1599-1670), who was later to translate the play into Dutch, used the phrase in the title for a satirical poem on courting, referring to the service the poet does to his friends in warning them about foolish lovers. Tesselschade may have known the poem, especially given Westerbaen's personal connection to Huygens. Westerbaen, fol. $\mathrm{C}^{\mathrm{r}}$. 
glasses blend a moral tendency with a penchant for play that undercuts that moralism.

Her sister Anna's glasses display this combination more overtly and with a great deal of variety. On the one hand, she gives the impression of virtue and Stoic moralism, but on the other hand, she seems keen to subvert that impression. During a visit in the early 1640s to Antwerp, Anna engraved a roemer and a berkemeyer with her own motto, "Genoech is meer als veel" ("Enough is more than a lot") (fig. 8), seemingly a clear statement favoring temperance. By this time, Anna frequently visited the Spanish Netherlands where she maintained various contacts, having converted to Catholicism after her marriage in 1624. These were friendship glasses, offered to prominent citizens of the city, one to the learned theologian Bartholomeus de los Rios (1580-1652) and the other to the wealthy merchant and patron Lodewijk de Roomer (b. ca. 1600). The engravings give advice to the person drinking from the glass and articulate a general principle by which Visscher wanted to live her life; as such, they are confident self-presentations offering a sentiment from a position of moral authority and passing that authority on from engraver to owner. Further details of the engravings, however, complicate the picture. The berkemeyer adds phrases in Latin and in Greek- "Plus est dimidium toto" and "ПАEON

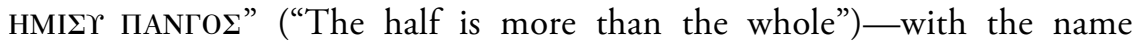
"Hesiod" on a small scroll. It was the Greek poet's motto, well known through the Adages (1540) of Desiderius Erasmus (1466-1536). ${ }^{73}$ The phrases are divided in segments and placed between and underneath the calligraphic inscription, "Anna Roemers has as a sign of friendship / Written this for the noble lord Loduvicus de Romer / Anno 1642."74 Beyond proving friendship, the glass creates a curious relationship between Visscher's own motto and Hesiod's adage. While Hesiod's phrase appears to authorize her own, the latter, presented in large lettering that encapsulates the smaller Latin and Greek lettering, overwhelms the former and, in its excess, seems to undermine the very idea of moderation.

The same goes for the glass itself. The berkemeyer is, as Smit remarks, large in size, creating an ironic relation between inscription and glass: "Considering that this large berkemeyer has a content of three liters, the inscription-in praise of moderation-seems rather humorous." 75 Another berkemeyer (fig. 9) features the morally similar phrase "Vincens tui," Latin for "Conquer yourself." Although the recipient and context for the engraving are unknown,

${ }^{73}$ Cf. "Dimidium plus toto": Erasmus, 228 (1.9.95).

${ }^{74}$ The calligraphy on the glass reads: "Anna Roemers heeft dit tot een teken van vrintschap / Geschreeven voor den Eedelen Heere Loduvicus de Romer / Anno 1642.”

${ }^{75}$ Smit, 1990, 51. 


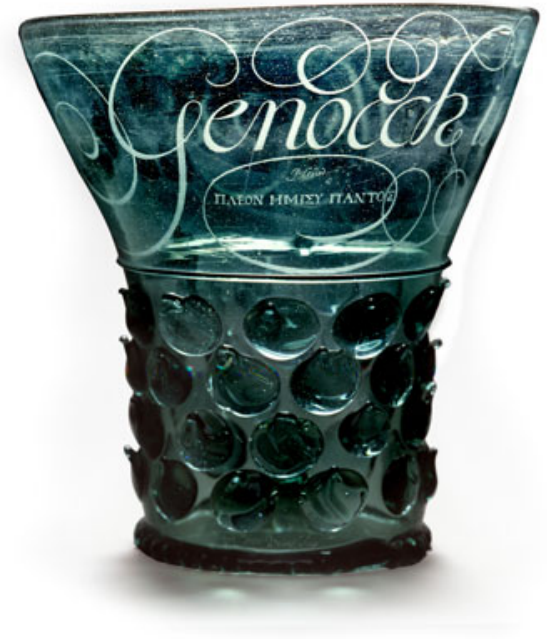

Figure 8. Anna Roemers Visscher. "Genoech is meer als veel," 1642. Engraved berkemeyer. Museum für Kunst und Gewerbe, Hamburg, 1904.446.

this is an obvious expression of the Stoic temperance regularly seen in Anna's and her father's work. Self-control is advocated because, as one of Roemer Visscher's emblems puts it, "Too much disgusts." 76 Yet, as is true for the other glass, this emphasis on moderation is subverted by the elaborate nature of the calligraphy. As one's eyes follow the decorative swirls of and around the letters, it can be difficult to concentrate on the content of the inscription. The aesthetic pleasure derived from the calligraphy runs counter to the message, creating a back-and-forth between the two and making one's reading of the glass dependent on one's own position as its recipient, beholder, or user. Play, thus, is located in the relationship between the substance of the inscription, the materiality of the glass, the style of the calligraphy, and the situation in which it is used or seen, creating the impression of a knowing wit on the part of the engraver.

Four glasses engraved in the early 1620 s, none of which are extant, show Visscher expanding upon the possibilities of her medium, conveying personal messages as well as public ones. On a much-publicized trip to Zeeland, made in 1622, Anna engraved glasses that function as counterpoints to the account of

\footnotetext{
76 “Alte walght." R. Visscher, 1614b, fol. Q3 ${ }^{\mathrm{r}}$ (emblem 3.1).
} 


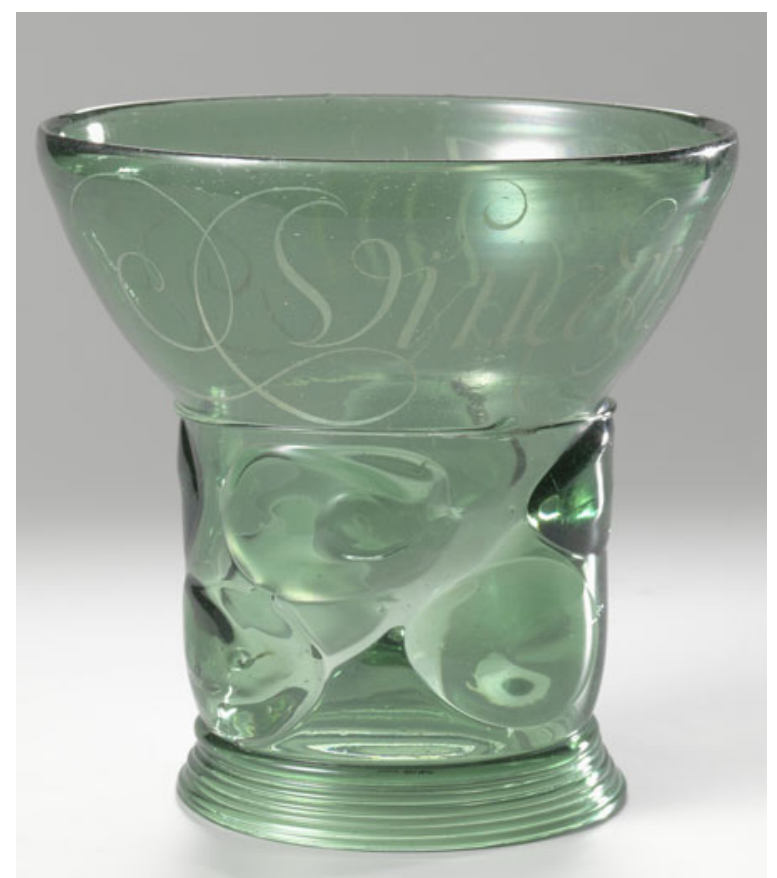

Figure 9. Anna Roemers Visscher. "Vincens tui," 1646. Engraved berkemeyer. Rijksmuseum, Amsterdam, BK-NM-8186.

her visit in the Zeeusche nachtegael (Nightingale from Zeeland, 1623), a volume of poetry written on the occasion by Visscher and others. The book includes poems in which fellow authors not only welcome and praise but also tease Visscher, mainly on the basis of her unmarried state. She responded wittily in a series of poems that create a narrative about her journey, arrival, and mysteriously unexpected quick departure, explained as a consequence of a squabble with Cupid. ${ }^{77}$ The poems on the engraved glasses were copied by Visscher herself in Letterjuweel (Jewel of letters, n.d.), a calligraphic manuscript she created of her own work; this suggests that she wanted to leave some sort of record of her engraved glasses, perhaps out of an awareness of their ephemeral nature, and even though a number of these engravings record particular moments in personal relationships, she seems to have wanted to make them part of her larger poetic oeuvre. On one of the glasses, presented to the poet and lawyer Simon van Beaumont (1574-1654), who also features prominently in the book, she expresses her delight in having arrived, not so much because of Zeeland's

${ }^{77}$ The poems by Visscher appear in Zeeusche nachtegael, fol. B4 ${ }^{\mathrm{r}}-\mathrm{C} 2^{\mathrm{r}}$. See for more discussion, Van Elk, 2017, 107-11. 
pleasant nature but because of the hospitality she received there. ${ }^{78}$ Another glass was engraved with a brief poem to fellow female author Johanna Coomans (1580/85-1659). According to the title of the poem Visscher wrote about the glass, it was engraved over dinner, highlighting the performative dimension of engraving - it seems to have become a show she could put on for others rather than, in the manner of Van Godewijck's poem, a skill she practiced in the home. ${ }^{79} \mathrm{~A}$ third engraving plays on male poets' tendency to equate engraver and glass and link the glass to the female body. This particular object was sent to a banquet Visscher could not attend due to her early departure from Zeeland. Its inscription encourages her friends to kiss the mouth of the glass instead of her and drink to her health. ${ }^{80}$ Finally, most unusually, Visscher engraved a glass for Van Beaumont with a quotation from Virgil, reading "Manet alta mente repostum" ("[The outrage] remains deep in her mind"). ${ }^{81}$ This engraving is known because of a poem Van Beaumont wrote in response, in which he wondered how he had insulted her. He promises to do penance but says he remains hopeful even if that does not work: "the threat which I read / May have been written in diamond, but on glass: / Glass is brittle, so is the anger in your thoughts." 82 No other engraved glass I have encountered has such a negative emotion expressed on it. In the Virgilian context, the quotation refers to Juno's anger at the judgment of Paris, a fact that suggests that Visscher was perhaps teasing Van Beaumont, though his poem does seem to take her words seriously; one would imagine he would be reminded of her "anger" every time he looked at or drank from the glass. These glasses not only showcased Visscher's ability to expand the range of social uses to which they could be put, but also enabled her to adopt a variety of personas and voices.

The most explicit act of self-representation, and the most sophisticated handling of the relation between calligraphy and material object, can be seen in one of the earliest of the extant engraved glasses by Anna, the roemer she sent to Huygens in 1619, to which he responded with the two poems cited above (fig. 10). Even more than her other glasses, this glass functions as equivalent to a poem, but ironically, she uses it to discuss her lack of poetic inspiration. The glass features Huygens's name as well as an epigram:

${ }^{78}$ A. R. Visscher, 1881, 2:122.

${ }^{79}$ The poem is entitled "Aen juffrouw Johanna Comans Daer ten Eeten sijnde op een Roemer Gheschreven" ("To miss Johanna Comans There while being over for Dinner Written on a Roemer”): A. R. Visscher, 1881, 2:116.

${ }^{80}$ A. R. Visscher, 1881, 2:143-44.

81 The quotation is from the Aeneid, 1.26; the translation by Frederick Ahl reads, "Juno had never let fall from her mind these causes of anger": Virgil, 30. A. R. Visscher, 1881, 2:180.

${ }^{82}$ The original reads: "het dreygen, dat ik las, / Was wel met diamant geschreven, maer op glas: / Glas is broos, so is oock den toorn in u gedachten": A. R. Visscher, 1881, 2:180. 


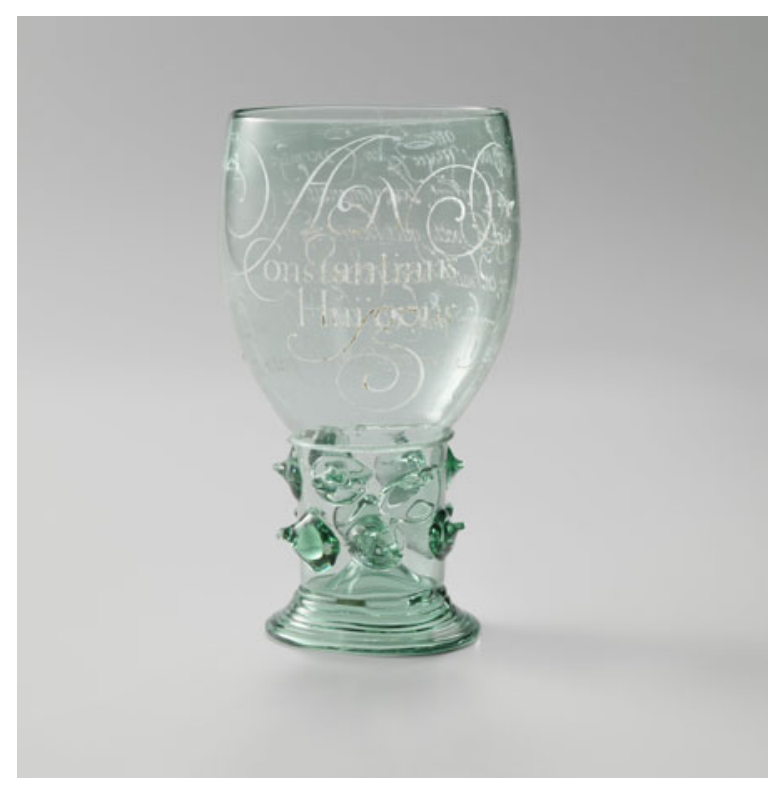

Figure 10. Anna Roemers Visscher. "Constantinus Huijgens," 1619. Engraved roemer. Rijksmuseum, Amsterdam, BK-1983-15.

Shriveled up so is my pen, dusty is my paper, rusty is my mind, moldy is my lyre.

Go, blessed poet, go hither to the tops of Helicon, and get some water to drop in my dried-up ink, so that I, as I was wont, with an ordinary pen may greet my friends. ${ }^{83}$

The poem was written at a time when Visscher was in charge of the family household after the death of her mother. At this moment, Huygens's literary career had only just begun. He was much impressed by Visscher and eager to enhance their friendship. There is a preoccupation with aging and barrenness in Visscher's poem, which contains surprisingly physical imagery. ${ }^{84}$ Although she is speaking of pen and paper, mind, and lyre, the words "Shriveled," "dusty," "rusty," and "moldy" are direct and detailed material adjectives that counter the

83 "Verschrookt zo is mijn pen, vermuft is mijn papier / verroest is mijn verstand, beschimmeld is mijn lier. / Gaat, zegenrijk poëet, gaat henen op de toppen / van Helicon, en haalt wat water, om te droppen / in mijn verdroogde inkt, opdat ik, als ik plach, / met een gewone pen mijn vrienden groeten mag": A. R. Visscher, 1999, 95.

${ }^{84}$ See Van Elk, 2017, esp. 90-92. 
praise poetry about her and their emphasis on her superior spirit and mind. Huygens's response, cited above for its creative comparison of engraving to ice skating, repeats the imagery of Anna's epigram to deny that he would be able to fetch her water and to urge her to be more confident about her writing and content with what she has, concluding,

Stop Your water-avarice,

If you are not allowed to write on paper,

Let your hand float in glasses

Is it not black, then it is white,

Do not seek more than you have. ${ }^{85}$

Huygens's poem is a reflection on loss and further develops the contrast between Huygens and Visscher, defined in terms of literary abilities but also in terms of grief, shame, and age. Interestingly, Huygens tells her to turn from poetry to glass engraving as compensation for her lack of inspiration. The liquid imagery used by Visscher leads to his use of the word drijven for engraving, which both means float (my choice here) and push, denoting feminine passivity as well as masculine activity in imagining the act of cutting the glass. Here, too, engraving conjures up conflicting images of the engraver's agency.

Visscher's work reflects intelligently and playfully on her self-representation, the representation of the recipient of the glass, and the materiality of the object. Anna is asking for a sip of Hippocrene in a vessel that is designed to contain liquid; she is herself comparable to the glass, which also needs liquid to fulfill its purpose. The words denoting her state of mind, which hardly seem to fit a glass designed for drinking wine, create a double impression of female modesty and ostentation. Considering the lettering, there is clearly nothing modest or humble about the large "Aen" ("To"). Typographically, the word contrasts with the letters with which she has engraved "Constaninus Huijgens," which are in smaller-sized roman script suggestive of a more controlled, and what might be called masculine, style, though the $g$ in the recipient's last name is unexpectedly decorated with calligraphic swirls. Moreover, the centrality of his name to the engraving is contrasted with the absence of her own name and signature. While Visscher presents herself in substantive, poetic terms as modest and lacking in inspiration, even leaving out her own name, her engraving nonetheless dominates the glass and employs lettering appropriate to manuscript and print to create a dual impression of her authorship and his. Perhaps most importantly, when empty, the transparency of the glass causes the

85 "Stopt V water-giericheyt, / Mooght ghy op papier niet schryven, / Laet u handt in glasen dryven, / Is 't niet swert zoo js het wit, / Soeckt niet meer dan ghy besit": Huygens, 1:142. 
engraving of Huygens's name and the engraving of the poem on the other side to blend. In spite of the insistence in their poems on the contrast between the two of them, the distinction between opposites (black/white, print/manuscript, roman lettering/chancery hand and calligraphy) collapses into one. This effect vanishes whenever the glass is filled with wine, proving that interpretation of the glass is not just dependent on perspective but also on the specific situation in which it is beheld. The contrast between expressed modesty and the dazzling nature of this artifact creates an irony that highlights the engraver's playful ability to question binary oppositions. It is a fine example of how glass engravings generated further texts and how they could position the engraver and recipient socially, while representing both in a new light, adhering to convention and subverting it at the same time.

\section{GLASS ENGRAVING AND THE NATURAL WORLD}

If the combination of the substance of the text, the calligraphy, the materiality of the glass, and the context in which the glass was presented, handled, and displayed complicates any reading of these engravings, the presence of imagery adds a further layer of interpretation. Although some engraved glasses featured portraits, the extant ones only include images of the natural world, especially insects, fruit, and flowers. The use of such images on engraved glass, apparently pioneered by Anna Visscher, allows these objects to speak to contemporary developments in natural history. As William Ashworth has clarified, the "cultural matrix" of natural history was made up of a variety of traditions, including the "bieroglyphic, antiquarian, Aesopic, mythological, adagial, and emblematic traditions," all of which were "densely interwoven." ${ }^{86}$ At the same time, natural history remained strongly motivated by the religious idea that nature gives access to the divine creator, an idea that was expressed in the notion of the natural world as the Book of Nature. ${ }^{87}$ But these complex webs of allusion and understanding were undergoing change. Brian Ogilvie has traced the gradual emergence of natural history as a discipline, showing its development from works that explained the medical uses of plants to books that revealed an increasing interest in plants for their own sake. Particularly important, Ogilvie shows, were the connections between natural history and a culture of collecting and curiosity, accompanied by an interest in detailed depictions of nature and an aesthetic approach to the natural world. ${ }^{88}$ It was not until late in the seventeenth century that natural historians concentrated on the

\footnotetext{
${ }^{86}$ Ashworth, 307. Italics in the original.

${ }^{87}$ See especially Jorink.

${ }^{88}$ Ogilvie, 209-64.
} 
classification of plants and animals. Major naturalists in the Dutch Republic, such as the botanist Carolus Clusius (1526-1609) and entomologists like Jan Goedart (1617-68), Maria Sybilla Merian (1647-1717), and Jan Swammerdam (1637-80), can all be placed in relation to these developments. As Eric Jorink has recounted, Huygens himself was deeply invested in new scientific discoveries, including the microscope, and he had his own collection of naturalia, or exotic natural objects. ${ }^{89}$ Placing an image of a plant or an insect on an engraved glass situated the glass culturally in relation to these changing perspectives on the natural world and, in light of the multiple, possibly conflicting interpretations that resulted, created openings for play. The images on glass inspire wonder by concentrating on the aesthetics of the natural world, but they also encourage reflection on the relationship between humans, art, and nature.

Inspiration for these images came not just from natural history itself but also from other art forms that were conventional female pastimes, including, most importantly, still-life painting and embroidery. ${ }^{90}$ While no embroidery by the Visscher sisters is extant, eight accomplished works of embroidery by Van Schurman have been preserved, including book covers and a sampler, some of which contain botanical and entomological images. ${ }^{91}$ Still-life paintings of flowers also often featured insects. These pictures, including those in glass engravings by the Visscher sisters and Van Schurman, are indebted to earlier sixteenth-century works of natural history on insects and to florilegia, books of flowers that were also used as pattern books for embroidery. Two images on a glass by Anna Visscher are known to have been copied from such printed sources. She used one of the earliest florilegia, the Florilegium (ca. 1590), by Adriaen Collaert (ca. 1560-1618), as well as Volatilium Varii Generis Effigies (Images of various types of flying creatures, 1594), by Nicolaes de Bruyn (1571-1656). $9^{92}$

In addition to Collaert and De Bruyn, an important influence on all three engravers, and on still-life painting generally, is the work of the famous illustrator and illuminator Joris Hoefnagel (1542-1601). Van der Stighelen points out that Van Schurman was familiar with Hoefnagel's art, and given that Huygens was a nephew of Hoefnagel and keeper of some of his manuscripts, it seems highly likely that all three were acquainted with his engravings and illuminations, which featured detailed images of insects, fruit, shells, and

${ }^{89}$ Jorink, 1-31.

${ }^{90}$ Honig, 35-36; Van der Stighelen, 240-58.

${ }^{91}$ Van der Stighelen, 240-58.

${ }^{92}$ Hudig, 177-83. Hudig, 180, argues that these glasses show evidence of an increasing trend toward naturalism in art more generally. 
plants. ${ }^{93}$ Hoefnagel's images were produced in a courtly context, for Emperor Rudolf II, but due to their realism they also drew on new interests in scientific discovery of the natural world. Janice Neri emphasizes their courtly and recreative quality, claiming that these images were

made to appeal to the highly refined sensibilities of late sixteenth-century courtly audiences, in particular the taste for the esoteric and the bizarre that is usually associated with mannerism, and as such they positioned him as the gatekeeper to a world filled with jewel-like treasures and curiosities. Hoefnagel's insect illustrations were perfectly calibrated to satisfy his audience's appetite for witty, sophisticated amusements while also establishing his identity as a figure who held the key to unraveling these tantalizing visual games. ${ }^{94}$

In other words, representations of plants and insects became for Hoefnagel not so much occasions for religious and moral expression, but instead opportunities for riddling play, teasing invitations to interpretation. Although Marisa Bass considers Hoefnagel's exile from Antwerp due to the Dutch Revolt more important than his courtly background, she also highlights his work's interpretive elusiveness. His animal imagery in The Four Elements (ca. 1575-82), she argues, is marked by a deliberate "mimetic obscurity." It was driven not by a scientific desire for certainty but by a fundamental doubt in truth more generally. ${ }^{95}$ Even more radically, his pictures of insects are "both an ode to the divine genius that surpasses human understanding and his ultimate argument against an anthropocentric view of the cosmos." 96 But, as Bass notes, Hoefnagel's late work also evokes a kind of playfulness, in "inventions unburdened by the weighty questions that consumed his private inquiries." ${ }^{\prime \prime}$ It is this playfulness that would prove particularly inspiring to female glass engravers, for whom "mimetic obscurity" could enhance the effect of wonder and pleasure.

The playfulness of Hoefnagel's work is particularly important in those drawings and engravings that place highly realistic objects from the natural world close to calligraphic lettering and text (fig. 11). His illuminations in the Mira Calligraphiae Monumenta (Model book of calligraphy) were added many years after the text had been written by calligrapher Georg Bocskay (1510-75). They create a rivalry between image and calligraphy, drawing attention away from the

${ }^{93}$ Van der Stighelen cites Guillaume de la Rivière, Van Schurman's biographer, who writes that she was inclined to imitate Hoefnagel. She speculates that Van Schurman's father had Archetypa Studiaque Patris Georgii Hoefnagelii (Archetypes and studies by George Hoefnagel his father, 1592), published by Hoefnagel's son Jacob, in his library. Van der Stighelen, 250.

\footnotetext{
${ }^{94}$ Neri, 4.

${ }^{95}$ Bass, 201-02.

${ }^{96}$ Bass, 230.

${ }^{97}$ Bass, 243.
} 


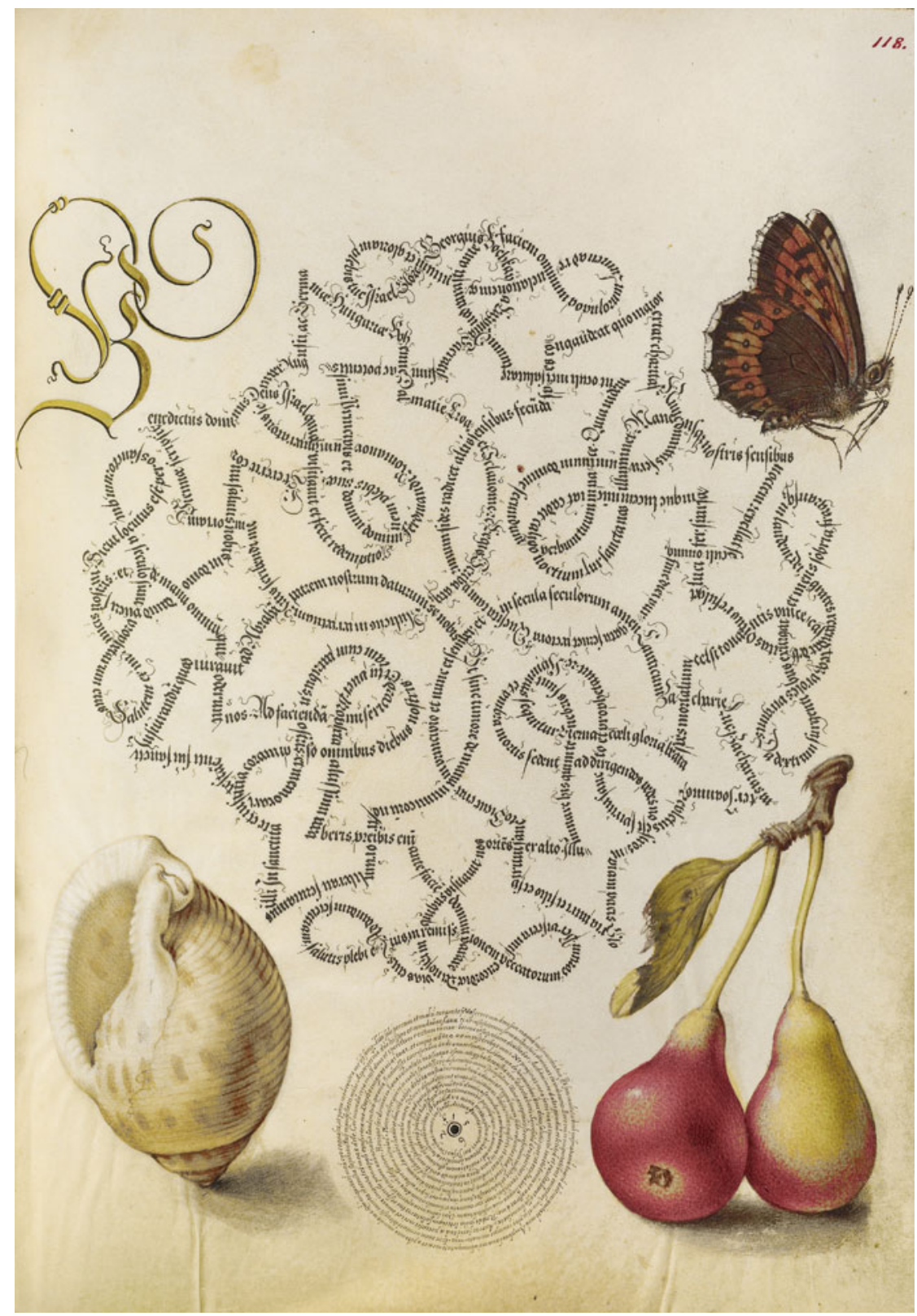

Figure 11. Joris Hoefnagel and Georg Bocskay. "Butterfly, Marine Mollusk, and Pear," Mira Calligraphiae Monumenta, fol. 118 ${ }^{\mathrm{r}}$, 1561-62; illuminations 1591-96. The J. Paul Getty Museum, Los Angeles, MS 20 (86.MV.527). 
content of the writing toward its aesthetic qualities. The resulting "mimetic obscurity" is also seen in glass engravings that feature insects and plants in close proximity to calligraphic text. Rather than pointing to an emblematic moral, still so important to much natural history at this time, the images on the glasses evoke an aesthetic response, as can be witnessed in Anna's glass engravings, which appear to delight in images for their own sake. On "Vincens tui" (fig. 9) for example, she engraved a butterfly, a fly, a violet, and a cherry, the latter done in stipple technique, the first extant Dutch example of stippling. ${ }^{98}$ Her "Hospitalitatis ergo" includes two butterflies and a plum, without apparent relevance to the inscription.

One of Visscher's earlier extant roemers, "Bella Dori gentil" ("Lovely and kind Doris") (fig. 12), demonstrates the impact of the images on the overall design and style of the glass. It displays the most elaborate visual decoration of all her glasses: a dragonfly, three flowers, and a conch shell, along with a short Italian poem of obscure origin taking up a modest amount of space. The poem reads, "Lovely and kind DORIS, We beautiful flowers / Derive our honor from you." 99 The glass may have been presented to Dorothea van Dorp, a friend of Anna's who was loved by Huygens and is named Doris in some of his poems. ${ }^{100}$ By contrast with the glass addressed to Huygens, the calligraphy on this glass is modest and inconspicuous, surrounded by images that take up most of the space. The name "DORIS" is in capital roman letters, reminiscent of the letters used for Huygens's name on the 1619 glass, to emphasize the sentiment of the poem: that the flowers derive their honor from the addressee or, perhaps, that the engraving derives its beauty from the recipient. The elements of the natural world are unrelated to the inscription, and the objects do not point to an overarching moral theme. ${ }^{101}$ Instead, they are decontextualized on the glass, a technique for which Neri uses the term "specimen logic," which imagines nature as a collection of objects. ${ }^{102}$ The transparency of the glass, when unfilled, greatly enhances this aesthetic quality, especially

${ }^{98}$ Such artistically groundbreaking work by an elite woman was not unusual: Honig has explained that it was precisely the freedom afforded elite women in their capacity as "amateur" artists that created this possibility, whereas male artists were more specialized and constrained by the expectations and rules of their guilds and professions: Honig, 33.

${ }^{99}$ The engraving reads "Bella DORI gentil, Noi vaghi fiori / Da te prendiam gli honori."

${ }^{100}$ Smit, 1990, 44.

${ }^{101}$ I depart here from the analysis of the glass by Smit, whose disparate explanations for the images (reading the dragonfly as a reference to a friend in her circle, the rose to a Chamber of Rhetoric, along with other allusions to Homer and Ovid) show the strained quality of their emblematic and symbolic interpretation. Cf. Smit, 1990, 44. Hudig, 179, sensibly sees no symbolic meaning at all.

${ }^{102}$ Neri, $10-29$. 


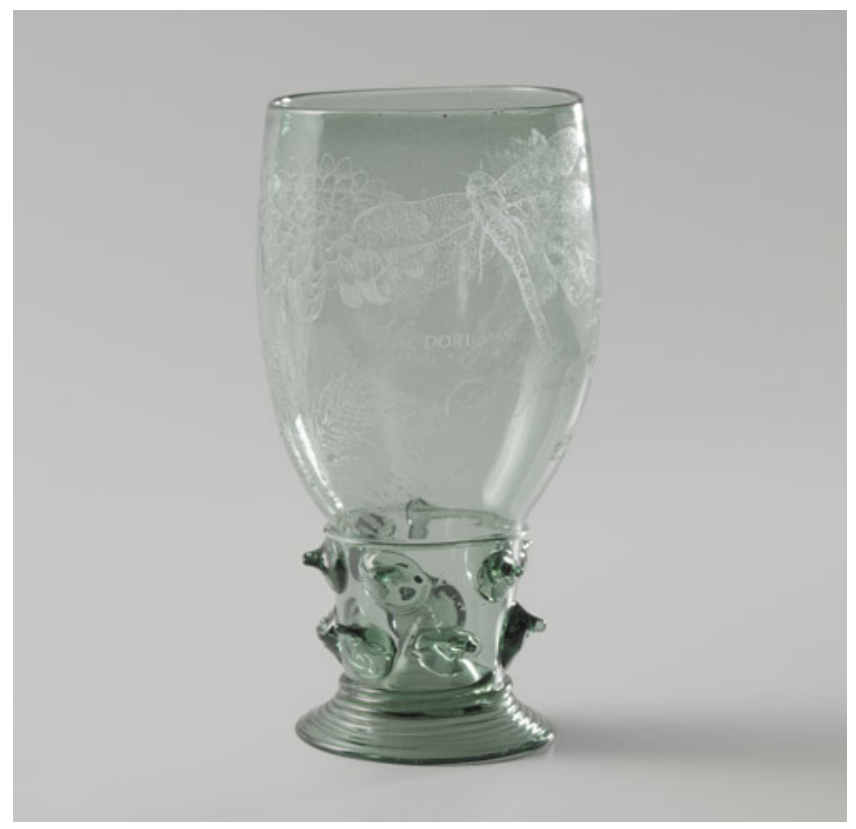

Figure 12. Anna Roemers Visscher. "Bella Dori gentil,” 1621. Engraved roemer. Rijksmuseum, Amsterdam, BK-NM-8188.

in the case of insects with transparent wings. Thus, the objects from the natural world arouse admiration and perhaps even desire, as Hooft's poem cited above suggests. The lush imagery gives the impression of sensuality, an impression that is countered by the emphasis on honor in the inscription. The combination of modest calligraphy, mythological reference, Italian language, and lavish imagery gives this glass a courtly, ornamental style.

This particular glass delights in elegance and refinement, representing the engraver unequivocally as masterly and sophisticated, but it is also reminiscent of the sexualization of glasses and their ability to spark desire in the beholder. The choice of the conch shell, typically a part of larger collections of items from the natural world, alongside the botanical and insect illustrations places this glass in conversation with natural history, pointing not so much to admiration for the divine maker of the Book of Nature or the importance of honor, but to man's dual desire to appreciate and own natural objects while also wanting to probe and understand the natural world. The glass evokes the desire to own it, drink from it, touch it, present it to guests, display it, and, in Hooft's case, cut off its insect. It also calls attention to a double act of appropriation: the engraver appropriates the natural world for the sake of aesthetic pleasure, and in turn the object itself is appropriated by the beholder and user of the glass. 
Tesselschade's "Sic soleo amicos" (fig. 7) is clearly indebted to Hoefnagel and provides a different reflection on the relationship between art and nature. Most glasses commissioned by Hooft specify only calligraphy. In the two cases when he did ask for images, he gave detailed instructions and drew his own designs. By contrast, "Sic soleo amicos" resembles engravings by Anna, with their insects and plants. The glass features a dragonfly, a mayfly, a beetle, and a spider about to catch a housefly. The spider, a common emblematic device, descends from the large $S$ onto an unsuspecting fly to offer a number of interpretive possibilities. As is true of the inscription itself, there may be a satirical gloss on the nature of friendship. Perhaps the image jokingly warns the friend of predatory treatment, but the roles may also be reversed, with the fly offering itself up voluntarily to the spider out of friendship. At the same time, this could be a clever allusion to Arachne, the weaver who competed with Athena, to comment on the use of the Athena reference to describe virtuous female pastime; the spider could stand in for Tesselschade herself, aligning her not with the patroness of crafts and wisdom, but with the victim of Athena's jealousy.

Were the spider the only image on the glass, its emblematic quality would control its meaning, but the added insects create greater complexity because they do not summon up conventional moral ideas. Instead, the Hoefnagellike closeness of the insects to the lettering creates further intriguing options for interpretation. Each of the insects has a somewhat different relationship to the letters-some use them and others are caught by them. The spider uses the particularly elaborate letter $S$ in $S i c$ as a place from which to descend on a thread; the mayfly is perched on the $S$ in Soleo; but the dragonfly appears caught by the end of the curl that comes from the capital $A$ in Amicos and moves all the way around the word. This curl also traps the beetle, which in moving toward the middle becomes a dot on the $i$. Thus, the insects depict different perspectives on the relation between art and nature: nature is indifferent to art, uses it in ways never intended by the calligrapher, but is also caught by it, either literally (as in the case of the dragonfly) or by becoming part of the lettering (as in the case of the beetle). At the same time, in gazing upon, displaying, and using the glass, the beholder turns the insects into collectible objects. How to read the relationship between the insects and the text remains uncertain and, at social gatherings, this enigmatic quality could have stimulated contemplation and conversation. This type of communal activity was, as noted above, a favorite pastime at the Visscher household and part of the sisters' education. The playfulness of the engravings suggests a similar approach, allowing for unconventional art as well as unconventional femininity, not covered by emblematic readings or pure aesthetics, but instead situated in the tension between the two. 


\section{GLASS ENGRAVING AND POLITICS}

Proving the potential for rich self-representation on the engraved glass, women also used engravings to voice political opinions and contribute to debates about national identity in the young republic. As Riet Schenkeveld-van der Dussen has argued, Anna Visscher was often co-opted in praise poetry in the service of identity formation: the presence of the exceptionally accomplished woman, functioning as a "tenth muse," was meant to indicate that the Dutch Republic was not a cultural backwater. ${ }^{103}$ The same was particularly true of Van Schurman. Yet these women wanted to voice their own ideas on Dutch identity and politics, and while household objects that were part of conspicuous consumption might not seem likely canvases for such ideas, they were open to them. Like the Visscher sisters, Van Schurman was highly aware of the possibilities for play in the combination of inscription, calligraphy, and glass. While her political and moral inscriptions can be forceful and almost singleminded, her calligraphy was very sophisticated, creating a double artistic vision. This style could also be adopted to espouse political ideas. For instance, she gave one of her Venetian goblets a political edge (fig. 13), capitalizing on the contradiction between the object as evidence of elite refinement and the object as vessel for such ideas. The inscription on the lid reads, "LONG LIFE IN JOY," and it says "Peace and Liberty" on the glass itself. ${ }^{104}$ Joy is therefore not defined in terms of physical pleasure, hospitality, or entertainment, but in the political terms provided on the glass, which become a correction of the inscription above; this reading can also be reversed, so that the inscription on the lid becomes a consequence of the declaration on the glass: peace and liberty lead to a joyous life. Van Schurman has used the duality of the goblet, with its glass and lid, to create an ambiguous statement: the viewer has to figure out, much as one might with an emblem, what the relation is between the glass, the engraving on the glass, and the engraving on the lid. The calligraphy itself, while simpler than is customary, is nonetheless visually striking, especially due to the transparency of the glass, and threatens to overwhelm the substance of the words. The swirling motion of the ascenders and descenders on the glass mimics the liquid nature of what might be inside it, creating a contrast with the more modest lettering on the lid. What the glass displays, then, is two different styleseach sober and forceful, but one more courtly and delightful than the other. The engraving allows for contemplation of the relationship between the two.

\footnotetext{
${ }^{103}$ Schenkeveld-van der Dussen gives an overview of the various praise poems composed on Anna, starting with the one of the earliest, by Heinsius, which shows that Visscher's "existence proves that the Netherlands have now indeed reached the level of the ancients": Schenkeveldvan der Dussen, 7.

${ }^{104}$ The inscriptions read "LANGE LEVE IN VREUGD" and "Vreede en Vryheid."
} 


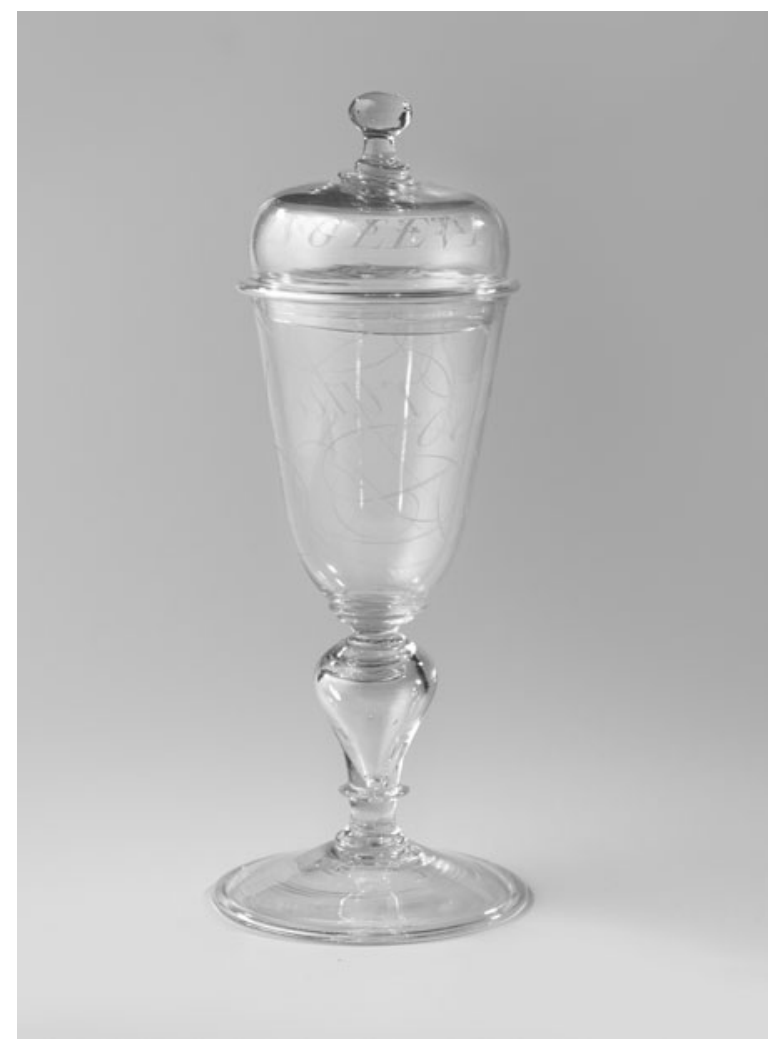

Figure 13. Anna Maria van Schurman. "Vreede en Vryheid," dated by Rijksmuseum ca. 1670ca. 1700. Engraved lidded goblet. Rijksmuseum, Amsterdam, BK-NM-740.

While the engravings discussed so far all have a more or less public component to them, either in their textual dissemination or in their use by and display to a larger group of people, a number of engraved glasses by Anna Visscher were actually made for public occasions or at the behest of institutions, taking them into the sphere of politics and out of the realm of personal gift exchange. These glasses could speak to a community through their engravings. This sets them apart from art forms like embroidery and manuscript poems, which, though also potentially presented to recipients of high status and with political intent, were not often guaranteed a larger audience in this way. When Anna engraved her public glasses, she tended to use Latin texts, as if to denote that the occasion required a shift away from the vernacular in which women usually wrote. She also took the opportunity to define her take on emerging concepts of Dutch identity, a subject with which her father had been deeply concerned in his emblems. One glass, lost since 1913, was engraved with the motto of the 
Dutch Republic in Latin. ${ }^{105}$ Another glass was engraved for the city of Dordrecht on the occasion of a 1623 visit by Visscher's friend, the extremely popular moralist Jacob Cats (1577-1660), with an inscription welcoming the author. A roemer was supposed to be engraved in 1630 as a reward for a poetry competition called by the Nederduytsche Academie (Dutch Academy), an institution that was intended to educate the general public. The glass does not survive, and so it is unknown if it was ever made, but the specific context is significant. Joost van den Vondel (1587-1679), the republic's most important playwright and prolific poet, had written a poem calling for the competitors to answer the question of whether freedom of religion mattered. The subject of religious toleration was close to Visscher's heart, as her emblem translations of De Montenay show, so it is not surprising that Vondel was able to rally her to his cause. ${ }^{106}$ The reward of his competition, he wrote, would be "A PRINCELY ROEMER. . . In which Pallas, with her diamond, / Cut the General of the land," the latter being a reference to Frederik Hendrik, Prince of Orange (1584-1647), who favored compromise in the religious conflicts of his day. ${ }^{107}$ The glass was to have a portrait of the prince on it, making it unlike all other engravings by Anna that survive. Vondel too equates the female engraver with Athena, this time presumably not merely for her craftsmanship but also for her political resonance and wisdom. He presents Visscher as giving expression to the needs of the country in a time of religious conflict, and this masculine agency allows for the unproblematic use of the word "cut" for engraving. Vondel's competition was controversial, but Visscher nonetheless agreed to it, presumably to argue for the need to overcome religious division; Tesselschade also joined in, writing a poem to enter in the competition. In the end, Vondel's plan was called off, but it reveals Visscher's willingness to use her engraving to further political ends publicly, even in controversial circumstances.

Another roemer with political significance was engraved in 1643, on a visit to Antwerp. The glass, no longer extant, was presented to the city council of Antwerp, which had offered Visscher a silver dish as a gift. The glass engraving, "Attrita resurget" ("Those who are bruised will rise again"), expresses confidence in the future rise of Antwerp after the occupation by the Spanish and the long-term blockade of the river Scheldt, which had crippled the city's economy. In a poem on the engraving, Visscher calls it the city's motto, but no such

105 "Concordia res parvae crescunt" or "Small things flourish by concord." Smit, 1990, 53.

${ }^{106}$ Van Elk, 2009.

${ }^{107}$ Whoever wins the competition, he says, will be honored "Met eenen PRINCENROEMER . . . / Daer Pallas, met haer diamant, / In sne den Veldheer van het landt": Smit, 1990, 49. 
motto is known to have existed, which suggests that she may have invented it. The glass featured a chamomile plant, as she explains in an accompanying poem: "There by Your Motto stands a Plant, / Which the more one steps on it / The more it grows wide and broad," using an image from nature not for decorative or aesthetic purposes but to bolster her political idea. She calls Antwerp "the most beautiful city / That the Netherlands has Ever had" and defiantly tells it to "Prosper Eternally to the shame and Regret / Of those who oppress and envy You." 108 The rhetoric is reminiscent of Calvinist poetics on the besieged chosen people, though Anna had long since converted from Calvinism to Catholicism herself, suggesting a smart appropriation of such language for a different cause. This glass, therefore, represents a departure from others, both in its strong political sentiment and the fact that it was part of a mutual gift exchange with a city, promising display to a larger audience. As is true for Van Schurman's glasses, it also showed that binary oppositions that regulated public femininity, between pastime and profession, domesticity and politics, and, in this case, Catholic and Protestant discourse, could be undone. This suggests the potential for glass engravings to forge a new kind of publicity for the woman engraver, allowing her to adopt a strong voice and offer an individual contribution to political debates normally considered off-limits for women.

\section{CONCLUSION: VAN SCHURMAN'S NAME}

I want to spend the concluding pages of this essay on a particularly remarkable engraved glass, one that combines the concerns I have explored so far with play, politics, sociability, art, nature, and above all self-representation. Van Schurman's reputation for learning and accomplishment had made her a key figure in the national imagination, and the attention and praise lavished on her made her uncomfortable. One of her abiding concerns, as witnessed in her self-portraits and autobiographical writing, was to fashion her reputation in ways she saw as desirable and that matched her strong religious conviction. This concern is apparent on the third of her surviving glasses. This example is a beaker, reminiscent of humpen beakers of the sixteenth century, made of dark green glass without enameling (fig. 14). It is inscribed with the name Viglius Zuichemus, with underneath the inscription, "Even though I shine darkly, I The Name gives luster." 109 The glass was evidently presented circa 1530 by

108 The original reads, "Daer bij V Sprueck staet een Gewas, / dat hoemen t'meer met voeten treet / dan wast het weelich wijd en breed." She calls Antwerp "schoonste stat / Die Nederlant Oijt heeft gehat. / Vaert Eeuwigh wel tot hoon en Spijt / Van die V druckt en u benijt": A. R. Visscher, 1881, 2:292.

${ }^{109}$ The Dutch reads, "Al schyn ick duyster / De Naem geeft luyster." 


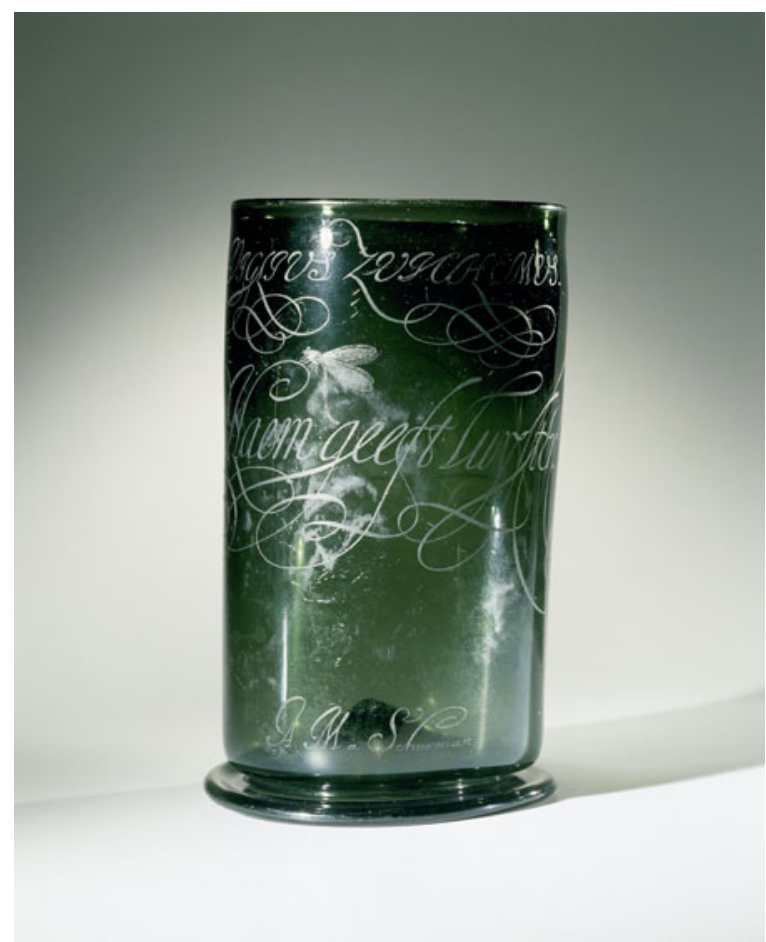

Figure 14. Anna Maria van Schurman. "Viglius Zuichemus," glass, ca. 1500-ca. 1600; engraving ca. 1630-70. Engraved beaker. Rijksmuseum, Amsterdam, BK-NM-8185.

the legal theorist Viglius Zuichemus (1507-77) to Charles V (1500-58) when the latter visited Utrecht and thus had great historical and local significance to the city. On what occasion Van Schurman engraved the glass is not known, but it is likely that it was a publicly significant commission by the city council. In light of the possibility of breakage during engraving (as was noted in Tesselschade's letter), the commission was a token of strong trust in the engraver. The glass would become the bearer of historic value in two ways: by commemorating the occasion of the visit and because of the moment of inscription by a famous inhabitant of Utrecht, who must have publicly presented the glass back to the city.

How did Van Schurman handle the doubly public nature of this engraving? This is the only extant engraving by Van Schurman to feature an image as well as text: on the $N$ for Name is a dragonfly. ${ }^{110}$ The date of the engraving is

${ }^{110}$ Van der Stighelen, 198, does note that there are references to glasses engraved with portraits by Van Schurman, but those are not extant. 
uncertain, but the dragonfly seems a deliberate allusion to the style of the Visscher glasses. Like the insects in those engravings, it creates a delicate tension between both image and lettering and art and nature, disturbing the historical quality of the glass with a timeless image from a natural world indifferent to the fame of the individuals named on the glass and the publicity that attends them. Moreover, the inscription itself plays on the dark color of the glass and its combination with the illustrious name of a famous inhabitant of Utrecht: the engraving adds to the shine and beauty of a dark surface, and the name Zuichemus on the glass gives it its importance. The delicate contrasts between the modesty of the glass and the decorative nature of the calligraphy and the insect are thus emphasized as much as the contrast between the object with no meaning in itself and the highly meaningful name that is inscribed on it. As Van der Stighelen notes, the engraving is a witty reflection on "the nature of the glass, the historical context, and her calligraphic skill." 111 Beyond wit, the glass invites contemplation on the relation between the material object and language, in particular in the form of names. Van Schurman is interested in the nature of the engraved glass as itself a signature, as was true for the roemers of the Visscher sisters and indeed any time a glass was engraved with someone's motto or name. Furthermore, as Lia van Gemert has noted, there is a possibility of a religious reference in the phrase, which can be read as contrasting the humble believer with the glory of the divine name. ${ }^{112}$

Beyond the references to nature, the historical occasion, and religious doctrine, the phrase on the beaker can be seen as a comment on Van Schurman's own position as woman writer in the public eye with a preference for a retired life, and thus as an intervention in her cultural representation. Van Schurman's vexed relationship with her own fame, which she would denounce late in life as motivated by vanity and idolatry, creates an ambivalent dynamic between retirement and display also seen in her self-portraits. ${ }^{113}$ That dynamic finds its expression in possible readings for the inscription, "Even though I shine darkly, / The Name gives luster." Does Van Schurman desire to have the kind of fame that only derives from the name, but not from the modest self? Or is there a complaint in her attempt to withdraw while still being given a reputation she has not asked for? The arrangement of the names adds to these conflicting meanings: "Viglius Zuichemus" is placed above the phrase, and a signature, "A. M. à Schurman," is engraved under it. The male name serves as heading and the female name as signature, but this placement presents the

${ }^{111}$ Van der Stighelen, 200.

${ }^{112}$ Van Gemert, unpublished response to the panel "Early Modern Women: Texts and Objects" at the Renaissance Society of America conference, Chicago, 2017.

${ }^{113}$ For more on this dynamic, see Van Elk, 2017, 167-214. 
option of seeing the inscription as a commentary on either or both, aligning the distinguished Zuichemus with Van Schurman herself, one present in large lettering and the other in modest writing, though with medium-sized initials. Van Schurman's signature thus functions as more than just a sign of the identity of the engraver. It incorporates her into the engraving as a whole, creating different options for figuring out what is meant by the inscription and the idea of the "Name" it highlights. More even than the Visscher sisters, Van Schurman playfully and artfully thematizes glass engraving as an act of self-representation as well as a representation of the other, in this case implicating the city of Utrecht and its artistic, cultural, and historical importance.

The complexity and multiple interpretive possibilities for this glass sum up what I see as the significance of all these engraved glasses. Through close reading, it becomes clear that these remarkable works of art cross boundaries that were self-evident in the early modern period and still seem self-evident today: between pastime and professional production, between public and private, between art and nature, between play and politics, and between different art forms. Engraved glasses could become public objects presented to important figures or even to cities, making political, moral, or religious statements. But they could also be given to a friend, inscribed with an emotion, or engraved over dinner in front of others. They could admonish sternly, proudly proclaim a motto, convey a personal sentiment, or echo what they were commissioned to say. They were useful as gifts, showing closeness to important individuals, elevating the status of both engraver and recipient in social networks, and complimenting or inviting others into those networks. The complexity of the glass engravings places them at the intersection of different ways of understanding and representing the world, ranging from emblems and embroidery to entomology and natural history. But the overwhelming impression one gets from the glasses is the playfulness with which they were engraved, their refusal to submit to singular interpretation, and the way in which they could be used to create unconventional self-representations for their female engravers. Much like the poetry of the Visscher sisters, the emblems of their father, the poetry of those who praised them, and the self-portraits of Van Schurman, these glasses show that Dutch culture was marked by two contradictory impulses: a devout moralism and a celebration of upsetting that same moralism through self-conscious play. Thus, glass engravings could convey opposing ideas and impressions at once, creating new, unconventional opportunities for self-expression and self-representation. 


\section{BIBLIOGRAPHY}

Alpers, Svetlana. The Art of Describing: Dutch Art in the Seventeenth Century. Chicago: University of Chicago Press, 1983.

Ashworth, William B., Jr. "Natural History and the Emblematic World View." In Reappraisals of the Scientific Revolution, ed. David C. Lindberg and Robert S. Westman, 303-32. Cambridge: Cambridge University Press, 1990.

Bass, Marisa Anne. Insect Artifice: Nature and Art in the Dutch Revolt. Princeton, NJ: Princeton University Press, 2019.

Bok, Marten Jan, and Jos de Meyere. "Schilderes aan haar ezel: Nieuwe gegevens over het schilderij van Gerard van Honthorst.” Oud Utrecht 58.12 (1985): 298-303.

Croiset van Uchelen, Ton. "Maria Strick, Schoolmistress and Calligrapher in Early Seventeenth-Century Holland.” Querendo 39 (2009): 83-132.

De Jeu, Annelies. "Eelckje van Bouricius: Een zeventiende-eeuwse dichteres in de marge van de literaire wereld." Tijdschrift voor Nederlandse taal- en letterkunde 114.1 (1998): 329-45.

Erasmus, Desiderius. Adages Iiv1 to Ix100. Vol. 32 of The Collected Works of Erasmus. Trans. R. A. B. Mynors. Toronto: University of Toronto Press, 1982.

Fleming, Juliet. Graffiti and the Writing Arts of Early Modern England. Philadelphia: University of Pennsylvania Press, 2001.

Frye, Susan. Pens and Needles: Women's Textualities in Early Modern England. Philadelphia: University of Pennsylvania Press, 2010.

"Gegraveerd glas van Maria Tesselschade ontdekt in beerput." Ed. Lillian Visser and Yuri Visser. Historiek. 14 April 2016. http://historiek.net/gegraveerd-glas-van-maria-tesselschade-gevonden/58330/.

De Geïntegreerde Taalbank: Historische woordenboeken Nederlands en Fries. 2007-18. Instituut voor de Nederlandse Taal. Cited as GTB.

Gell, Alfred. Art and Agency: An Anthropological Theory. Oxford: Clarendon Press, 1998.

Heinsius, Daniel. Nederduytsche poemata. Amsterdam, 1616.

Henkes, Harold E. Glas zonder glans: Viff eeuwen gebruiksglas uit de bodem van de Lage Landen 1300-1800 / Glass without Gloss: Utility Glass from Five Centuries Excavated in the Low Countries 1300-1800. Rotterdam: Coördinatie commissie van advies inzake archeologisch onderzoek binnen het resort Rotterdam, 1994.

Hiddes, Jos. "Kunstenaressen in de marge? Over knipkunst, calligrafie en roem." In Vrouwen en kunst in de Republiek (1998), 107-17.

Hieronymus. Commentarii. Ed. J.-P. Migne. Paris, 1845. Monumenta Informatik. http:// monumenta.ch/latein/xanfang.php?n=21.

Honig, Elizabeth Alice. “The Art of Being 'Artistic': Dutch Women's Creative Practices in the 17th Century.” Women's Art Journal 22.2 (Autumn 2001-Winter 2002): 31-39.

Hooft, P. C. Liederen en gedichten. Ed. Johan Koppenol. Amsterdam: Athenaeum, 2004.

Houbraken, Arnold. De groote schouburgh der Nederlantsche konstschilders en schilderessen. 3 vols. Amsterdam: Israel, 1976.

Hudig, Ferrand. "Graveerwerk van Anna Roemers Visscher." Oud Holland 41 (1923-24): 175-83. 
Huygens, Constantijn. De gedichten van Constantijn Huygens, naar zijn handschrift uitgegeven. Ed. J. A. Worp. 9 vols. Groningen: Wolters, 1892-99.

Jansen, Jeroen. "P. C. Hooft, lecteur et imitateur de Montaigne." In Montaigne and the Low Countries (1580-1700), ed. Paul J. Smith and Karl A. E. Enenkel, 173-85. Leiden: Brill, 2007.

Jorink, Eric. Reading the Book of Nature in the Dutch Golden Age, 1575-1715. Trans. Peter Mason. Leiden: Brill, 2010.

Klein, Lisa M. "Your Humble Handmaid: Elizabethan Gifts of Needlework." Renaissance Quarterly 50.2 (1997): 459-93.

Kloek, Els. "Vrouwen en het kunstenaarsleven van de Republiek. Een inleiding." In Vrouwen en kunst in de Republiek (1998), 9-19.

Laan, Cora. Drank en drinkgerei: Een archeologisch en cultuurhistorisch onderzoek naar de alledaagse drinkcultuur van de 18e-eeuwse Hollanders. Amsterdam: De Bataafsche Leeuw, 2003.

Margolin, Jean-Claude. “Georgette de Montenay, ses 'Emblèmes ou Devises Chrestiennes,' et Anna Roemers Visscher.” Bibliothèque d'Humanisme et Renaissance 51.2 (1989): 419-23.

Moerman, Ingrid W. L. "Kalligrafie: Echte nationale dilettantenkunst." Nieuw letterkundig magazijn 16.1 (1998): 23-25.

Montaigne. Les Essais. Ed. Pierre Villey. 3 vols. 2nd ed. Paris: Quadrige PUF, 1992.

Neri, Janice. The Insect and the Image: Visualizing Nature in Early Modern Europe, 1500-1700. Minneapolis: University of Minnesota Press, 2011.

Ogilvie, Brian W. The Science of Describing: Natural History in Renaissance Europe. Chicago: University of Chicago Press, 2006.

Olivétan, Pierre Robert, trans. Le nouveau testament. Paris, 1535.

Plutarch. Plutarch's Morals. Ed. and trans. William W. Goodwin et al. 5 vols. Boston, MA: Little, Brown, and Company, 1874.

Reinders, Sophie. De mug en de kaars: Vriendenboekjes van adelijke vrouwen, 1575-1640. Nijmegen: Vantilt, 2017.

Ritsema van Eck, P. C. "Bastiaan Boers en Mathieu Petit, schrijfmeesters, schoonschrijvers en glasgraveurs." Bulletin van het Rijksmusum 30.2 (1982): 51-62.

Schenkeveld-van der Dussen, M. A. "Anna Roemers Visscher: De tiende van de negen, de vierde van de drie." Jaarboek van de maatschappij der Nederlandse letterkunde (1979-80): $3-14$.

Smit, F. G. A. M. Uniquely Dutch Seventeenth-Century Calligraphy on Glass: A Preliminary Catalogue. Peterborough: n.p., 1989.

Smit, F. G. A. M. Anna Roemers and Maria Tesselschade and Their Engravings on Glass. Peterborough: n.p., 1990.

Smit, F. G. A. M. Uniquely Dutch Eighteenth-Century Stipple-Engravings on Glass: A Systematic Catalogue with Keys for the Identification of the Engraved Glasses. Peterborough: n.p., 1993.

Smits-Veldt, Mieke B. Maria Tesselschade: Leven met talent en vriendschap. Zutphen: Walburg Pers, 1994.

Strauss, Jerome. "The Diamond-Engraved Glasses of Elisabeth Crama." Journal of Glass Studies 12 (1970): 136-39.

Terence. Eunuchus. Ed. John Barsby. Cambridge: Cambridge University Press, 1999. 
Thoen, Irma. Strategic Affection? Gift Exchange in Seventeenth-Century Holland. Amsterdam: Amsterdam University Press, 2007.

Van der Stighelen, Katlijne. Anna Maria van Schurman of 'Hoe hooge dat een maeght kan in de konsten stijgen.' Leuven: Leuven University Press, 1987.

Van Elk, Martine. "Courtliness, Piety, and Politics: Emblem Books by Georgette de Montenay, Anna Roemers Visscher, and Esther Inglis." In Early Modern Women and Transnational Communities of Letters, ed. Anne R. Larsen and Julie D. Campbell, 183-210. Farnham: Ashgate, 2009.

Van Elk, Martine. Early Modern Women's Writing: Domesticity, Privacy, and the Public Sphere in England and the Dutch Republic. London: Palgrave Macmillan, 2017.

Van Elk, Martine. "Capable of Bruising a Letter: Early Modern Women's Calligraphy." Early Modern Women: Lives, Texts, Objects (16 February 2018). https://martinevanelk.wordpress. com/2018/02/16/capable-of-bruising-a-letter-early-modern-womens-calligraphy/.

Van Gelder, H. E. “Aanteekeningen over Willem Kalf en Cornelia Pluvier.” Oud Holland 59.1-2 (1942): 37-46.

Van Godewijck, Margareta. "Gedichten van Margareta Godewyck, met XXVIII door haar geschilderde zinne-beelden.” 1641-55. Regionaal Archief Dordrecht MS 1024.

Virgil. Aeneid. Trans. Frederick Ahl. Oxford: Oxford University Press, 2008.

Visscher, Anna Roemers. Alle de gedichten van Anna Roemers Visscher. Ed. Nicolaes Beets. 2 vols. Utrecht: Beijers, 1881.

Visscher, Anna Roemers. Gedichten van Anna Roemersdochter Visscher: Een bloemlezing met inleiding en commentaar. Ed. Riet Schenkeveld-van der Dussen and Annelies de Jeu. Amsterdam: Amsterdam University Press, 1999.

Visscher, Maria Tesselschade Roemers et al. Een onwaerdeerlycke Vrouw: Brieven en verzen van en aan Maria Tesselschade. Ed. J. A. Worp. Utrecht: Hes, 1976.

Visscher, Roemer. Brabbeling van Roemer Visscher: By hem selven overzien, en meer als de helft vermeerdert. Amsterdam, 1614a.

Visscher, Roemer. Sinnepoppen. Amsterdam, 1614b.

Visscher, Roemer. Brabbeling (1614): Een bloemlezing. Ed. Anneke C. G. Fleurkens. Hilversum: Verloren, 2013.

Vrouwen en kunst in de Republiek: Een overzicht. Ed. Els Kloek, Catherine Peters Sengers, and Esther Tobé. Hilversum: Verloren, 1998.

Westerbaen, Jacob. Minne-dichten. 's-Gravenhage, 1624.

Woodbridge, Linda. "Patchwork: Piecing the Early Modern Mind in England's First Century of Print Culture." English Literary Renaissance 23.1 (1993): 5-45.

Yeoman, Victoria. "Speaking Plates: Text, Performance, and Banqueting Trenchers in Early Modern Europe." Renaissance Studies 31.5 (2017): 755-79.

Zeeusche nachtegael, ende Des selfs dryderley gesang. Middelburg, 1623. 